\title{
The Malpaisillo Formation: A sequence of explosive eruptions in the mid to late Pleistocene (Nicaragua, Central America)
}

\author{
Line Stoppa ${ }^{\mathrm{a}}$, Steffen Kutterolf ${ }^{\mathrm{b}, *}$, Juanita Rausch $^{\mathrm{a}}$, Bernard Grobety ${ }^{\mathrm{a}}$, Thomas Pettke ${ }^{\mathrm{c}}$, \\ Kuo-Lung Wang ${ }^{\mathrm{d}, \mathrm{e}}$, Sidney Hemming ${ }^{\mathrm{f}}$ \\ a Department of Geosciences, University of Fribourg, Ch. Du Musée 6, CH-1700 Fribourg, Switzerland \\ b GEOMAR Helmholtz Center for Ocean Research Kiel, 24148 Kiel, Germany \\ c University of Bern, Institute of Geological Sciences, Baltzerstrasse 1+3, CH-3012 Bern, Switzerland \\ d Institute of Earth Sciences, Academia Sinica, Taipei 11529, Taiwan \\ e Department of Geosciences, National Taiwan University, Taipei, Taiwan \\ f Lamont-Doherty Earth Observatory/Columbia University, Palisades, New York 10964, USA
}

Keywords:

Explosive volcanism

Tephrostratighraphy

Pleistocene

Nicaragua

Malpaisillo and Monte Galán Calderas

\begin{abstract}
A B S T R A C T
The subduction-related volcanic front in Nicaragua consists of the Tertiary "Coyol" member in the eastern highlands and the Quaternary to recent volcanic arc within the Nicaraguan depression. Although the Holocene to recent explosive volcanism has been studied extensively no detailed work has been done on the products of explosive volcanism from Quaternary volcanic complexes comprising also the Malpaisillo and Monte Galán Calderas, the focus of this study.

The 11 km-wide Malpaisillo Caldera and 3.5 km-wide Monte Galán Caldera, located 50 km northwest of Managua, are surrounded by tens of meters of rhyolitic tephras. These pyroclastic flow and fall deposits extend proximally at least $11 \mathrm{~km}$ to the southeast and $23 \mathrm{~km}$ to the southwest, with observed depositional thicknesses of $>16 \mathrm{~m}$ for a single ignimbrite unit (or $>25 \mathrm{~m}$ for the entire section). Distal deposits are found as far as $350 \mathrm{~km}$ offshore in the Pacific. At least twelve highly explosive large-volume eruptive phases with corresponding tephra deposits (LPT $=$ La Paz Centro Tephra, PPT $=$ Punta de Plancha Tephra, LCbT $=$ Lower Chibola Tephra, GT $=$ Guacucal Tephra, UCbT = Upper Chibola Tephra, FeT = La Fuente Tephra, ST = Sabanettas Tephra, MgT = Miralago Tephra, ToT = Tolapa Tephra, LMT, MMT, UMT = Lower, Middle, and Upper Maderas Negras Tephras) are distinguished based on geochemical correlations and similar depositional characteristics. Radiometric ${ }^{40} \mathrm{Ar} /{ }^{39} \mathrm{Ar}$ ages indicate that most activity related to the large Malpaisillo Caldera occurred between $\sim 570$ and 420 ka. The large Pleistocene Malpaisillo and Monte Galán Calderas are characterized by a long-lived history and, if evolved, a distinctly alkaline $\left(\mathrm{K}_{2} \mathrm{O}=2.3-3.8 \mathrm{wt} \%\right.$; $\left.\mathrm{Na}_{2} \mathrm{O}=4.0-4.9 \mathrm{wt} \%\right)$ geochemical signature compared to the other Nicaraguan tephra deposits. As a result, the previously defined Malpaisillo Formation has been considerably extended and revised. Our findings contribute to fill a considerable gap in the long-term eruptive history of Nicaraguan volcanoes, with prominent implications for volcanic hazard evaluation for Nicaragua.
\end{abstract}

\section{Introduction}

The Nicaraguan volcanic arc is part of the Central American Volcanic Arc (CAVA), which extends from Guatemala to Costa Rica (Fig. 1), and has been active since at least the Miocene. Its explosive activity range in size, style, and composition from small, magnitude 1 to 3 , basaltic to andesitic eruptions, to very large cataclysmic, magnitude 4 to 6 , dacitic to rhyolitic eruptions. Eruption styles range from frequent strombolian eruptions producing scoria cones and strato volcanoes, to

\footnotetext{
* Corresponding author.

E-mail address: skutterolf@geomar.de (S. Kutterolf).
}

seldom occurring, partly ignimbrite-forming, plinian to ultraplinian eruptions of caldera systems. The respective volcanic history can be divided into two major phases: (1) the Neogene to early Pleistocene/Pliocene ( $>\sim 1.5 \mathrm{Ma}$ ) including the "Coyol arc" volcanism located $\sim 150 \mathrm{~km}$ eastward of the coast in the central part of the country (e.g. Schindlbeck et al., 2016b; Ehrenborg, 1996; Fig. 2) and (2) the Upper Pleistocene to recent volcanic front situated close $(\sim 70 \mathrm{~km})$ to the Pacific coast in the Nicaraguan depression (e.g. Kutterolf et al., 2007, 2008a; Bice, 1985). Between the early Pleistocene/Pliocene and the Upper Pleistocene the volcanic history has remained largely unknown, and less volcanic activity has been postulated due to a slab rollback at the Nicaraguan subduction zone resulting in a shift of the volcanic front $80 \mathrm{~km}$ to the west 


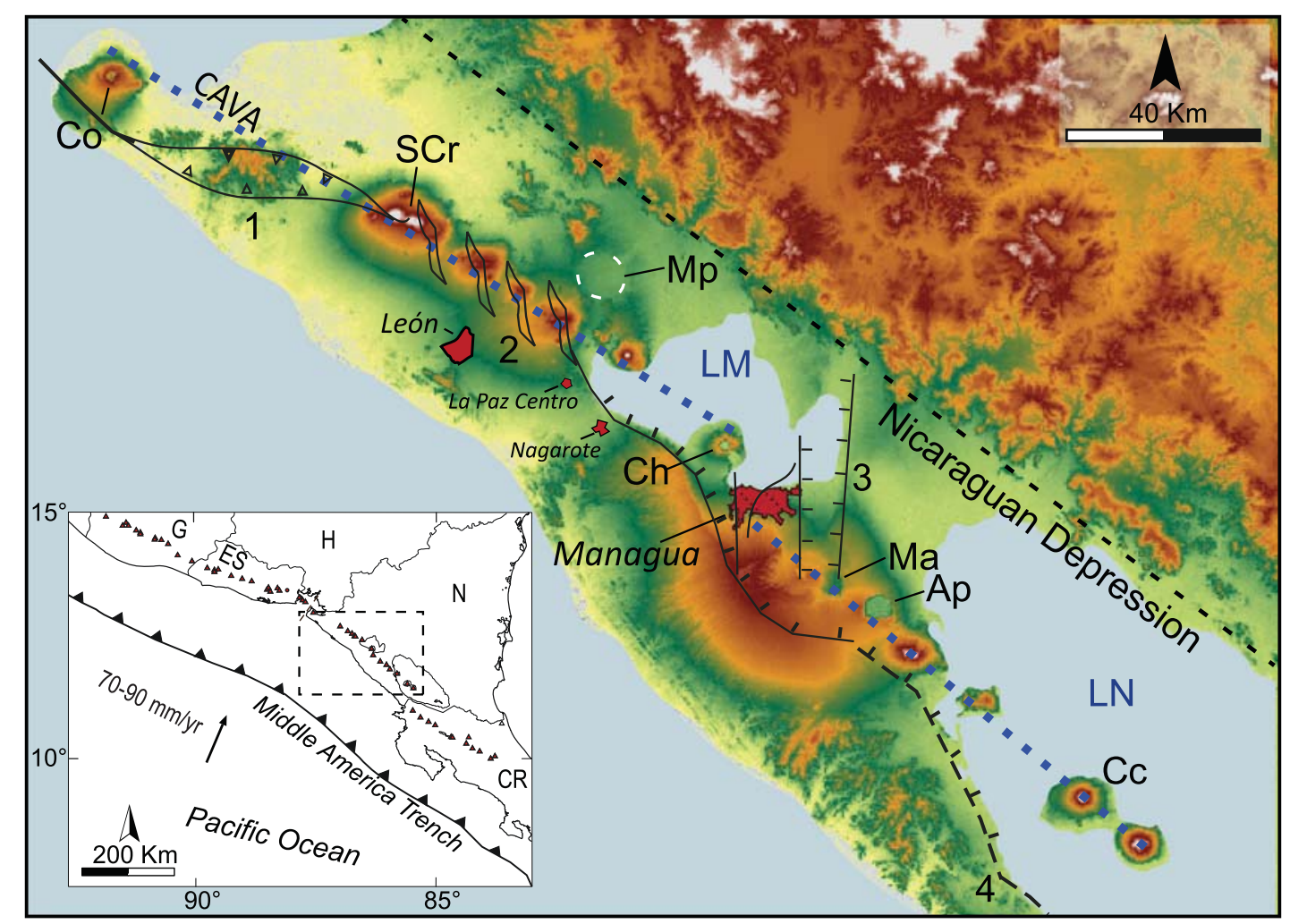

Fig. 1. Digital elevation model of western Nicaragua with the Lake Managua (LM), Lake Nicaragua (LN) and the CAVA (thick blue dashed line), which are all situated within the Nicaraguan Depression. The latter is limited to the northeast by a sudden change in elevation (black dashed line) and to the southwest by a series of transtensional structures (where $1=$ Congo restraining bend, 2 = Marabios en echelon faults including the La Paz Centro-Malpaisillo Lineament, 3 = Managua releasing bend, $4=$ Cocibolca transtensional segment; boundaries after Funk et al., 2009). The volcanoes responsible for widespread Quaternary tephras (Co = Cosigüina Volcano, SCr = San Cristobal Volcano, Ch = Chiltepe Volcanic Complex, Ma = Masaya Caldera, $\mathrm{Ap}=$ Apoyo Caldera, $\mathrm{Cc}=$ Concepción Volcano) and the Malpaisillo Caldera (Mp) are shown.

(Schindlbeck et al., 2016b; Ehrenborg, 1996; DeMets, 2001; Plank et al., 2002; Carr et al., 2007a; Saginor et al., 2011a, 2011b).

The Malpaisillo Caldera system, located in between the two volcanic fronts, is visible in satellite imagery and elevation models (Figs. 1, 2). It is mentioned in several publications (e.g. Bice, 1985; Kutterolf et al., 2007; Geilert et al., 2012) but has never been studied in detail. Its eruption sequence may close the time gap between the Coyol phase and the recent volcanism in Nicaragua and may represent the largest Quaternary eruptive events evident in central western Nicaragua.

This paper focuses on the detailed reconstruction of the tephra succession of the Malpaisillo Formation, particularly on stratigraphic and compositional relationships and the related eruption history. Identifying eruptive products from other sources and investigating the tephra dispersal characteristics of all units will help to integrate the new deposits into the existing tephra chronostratigraphy of the region and to extend the latter into a period for which the volcanic history is so far poorly known.

\section{Geological setting}

\subsection{The Central American Volcanic Arc (CAVA)}

The CAVA formed in response to subduction (7-9 cm/yr) of the Farallón Plate beneath the Caribbean during the Paleogene and subduction of the Cocos Plate from the Neogene to Quaternary (Fig. 1; e.g. DeMets, 2001; Barckhausen et al., 2001). The crustal thickness in Nicaragua is the smallest of the CAVA $(\sim 32 \mathrm{~km})$, whereas the slab dip is the steepest $\left(65^{\circ}-75^{\circ}\right.$ below the volcanic front (Shaw et al., 2003; Syracuse and Abers, 2006; Wehrmann et al., 2006, 2014).
Within the Miocene, the Coyol volcanic arc was active along the Pacific coast of the Chortis block (Fig. 2; Ehrenborg, 1996). During the Pliocene to Pleistocene, slab roll-back shifted the arc volcanism southwestwards to its actual position, 150-200 km away from the Middle America trench, at the same time as the Nicaraguan intra-arc depression formed (Mann et al., 2007; Funk et al., 2009).

The presently active volcanic front extends from Guatemala to Costa Rica, bound to the north by a zone of strike-slip faults that separates the Caribbean and North American plates (Carr et al., 2007a, 2007b) and to the south by the Hess escarpment (Dengo, 1985). Due to the oblique convergence and strain partitioning $(\sim 14 \mathrm{~mm} / \mathrm{yr}$ dextral shearing; Morgan et al., 2008), the CAVA is tectonically divided into ten segments (DeMets, 2001). Each of these segments extends 100 to $300 \mathrm{~km}$ and is separated by a 10 to $40 \mathrm{~km}$ long SW/NE offset such that the trencharc distance increases southward on each segment (Freundt et al., 2014).

\subsection{Geology of Nicaragua}

Nicaragua can be divided, from west to east, into the Pacific Coastal Plain, the Nicaragua Depression, the Interior Highland, and the Atlantic Coastal Plain (Weyl, 1980). The Nicaraguan Depression, a NW-SE trending, $45 \mathrm{~km}$-wide tectonic graben within the Pacific Coastal Plain, has been subsiding since at least the Miocene and is filled with approximately $6 \mathrm{~km}$ of volcaniclastic, lacustrine, and marine sediments (Fig. 1; McBirney and Williams, 1965; Weyl, 1980; Funk et al., 2009). Since the early Pleistocene this depression has contained two large lakes, Lake Nicaragua and Lake Managua. The oldest dated volcanic rocks so far ( $330 \pm 20 \mathrm{ka}$, sector of Telica Volcano; Carr et al., 2007a), suggest that the actual Nicaraguan volcanic front started possibly in the late Pleistocene. It lies within, and to the west of the Nicaraguan 


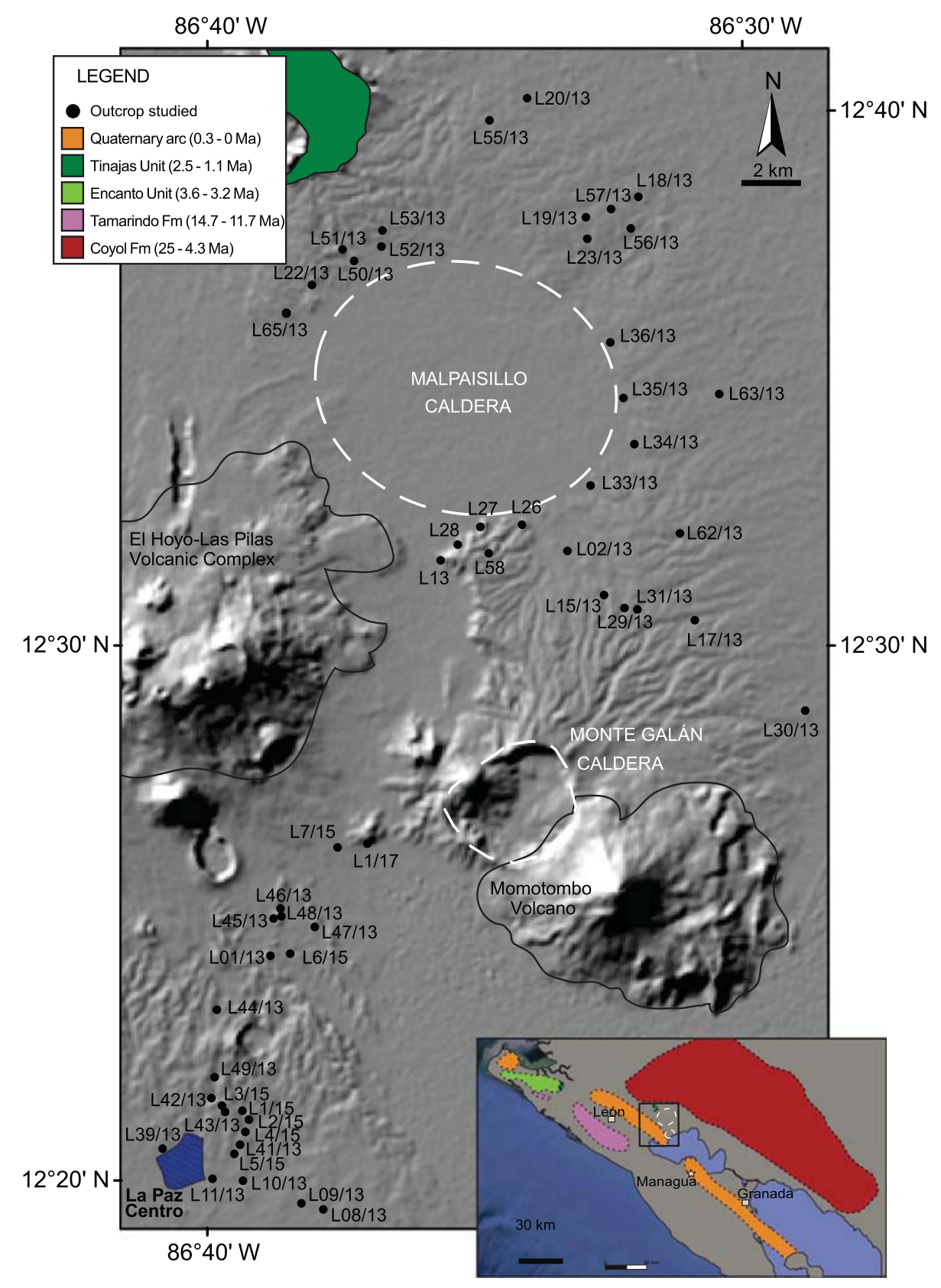

Fig. 2. Digital elevation model of the mapped area with studied outcrops. The inset illustrates the Quaternary volcanic front (in orange) and the other Nicaraguan volcanic formations up to the Miocene. The Upper Pleistocene volcanic edifices of the area are indicated in orange colors within the main map.

Depression, crossing both lakes and hosts also the Malpaisillo and Monte Galán Calderas. It is composed of at least 12 major volcanic complexes that have been active during the Holocene, including 6 presently active volcanoes.

\subsection{Tephrostratigraphy and volcanology}

A detailed Quaternary tephrostratigraphy exists only for the centralwestern region of Nicaragua. Bice (1985) described first a sequence of seven widespread tephra layers for the region of Managua. It was revisited and complemented by Kutterolf et al. (2007 and references therein) comprising now 15 tephra layers, which were ordered into two stratigraphic groups according to their volcanic sources. To the south, the Managua-Masaya Group includes the younger, Upper Pleistocene Managua, and the older Las Sierras Formations (Apoyo and Masaya Calderas; Freundt et al., 2006a, 2006b, 2010; Kutterolf et al., 2007; Peréz et al., 2009; Schmincke et al., 2010, 2009; Wehrmann et al., 2006, 2016). The latter has been estimated to be older than $~ 30$ ka (Kutterolf et al., 2007, 2008a; Schindlbeck et al., 2016a, 2016b). In the north, Kutterolf et al. (2007) defined initially the Malpaisillo Formation north of Lake Managua as well as the Xolotlán Group, whose deposits are related to vents on or near the Chiltepe peninsula. The Xolotlán Group consists of the Upper Pleistocene Chiltepe Formation lying unconformably on top of the older ( $>17 \mathrm{ka}$ ) Mateare Formation that contains deposits of mafic to intermediate compositions (Kutterolf et al., 2011). The analysis of offshore drill cores complements this stratigraphy with older layers up to the Miocene (Kutterolf et al., 2008a; Schindlbeck et al., 2016a, 2016b).

Onland tephrostratigraphic studies of widespread tephras elsewhere in Nicaragua are not as comprehensive and limited to incomplete tephra succession and ages (e.g. Cosigüina Caldera, Scott et al., 2006, Longpré et al., 2014a, 2014b; San Cristobal Volcanic Complex, Hazlett, 1987; Concepción Volcano, Borgia and de Vries, 2003). 
Malpaisillo Caldera, a few kilometers east of the actual volcanic front in the north of Lake Managua, is a nearly circular caldera $(\sim 10 \times 11 \mathrm{~km})$ at $70-110 \mathrm{~m}$ altitude with a slight morphological east-west inclination. The western edge of the Malpaisillo Caldera is bound by the La Paz Centro-Malpaisillo Lineament (LPML), one of the en echelon northeast-trending structures, which is covered by tuff rings and cinder cones (Geilert et al., 2012). The much smaller and even less studied Monte Galán Caldera, with its $\sim 4 \mathrm{~km}$ diameter, is located $10 \mathrm{~km}$ to the south of the Malpaisillo Caldera rim at the slope apron of the Momotombo volcano. Their related products (alkali-rich rhyolitic ignimbrite, surge and minor ash fallout) that crop out in the plains between Nagarote, La Paz Centro, El Hoyo, and Momotombo were mentioned and roughly mapped by several authors (e.g. Bice, 1985; Hradecky, 2001; Kutterolf et al., 2007) but so far not studied in detail. Van Wyk de Vries (1993) postulated an age estimation of $>50 \mathrm{ka}$ for the Malpaisillo eruptive products based on field relationships.

\section{Methods}

\subsection{Field work}

We studied the stratigraphy and lithology of 53 outcrops (Figs. 2 to 5; supplementary Fig. 1; supplementary datas 1,2 ) extending from the caldera rim to medial areas around the Malpaisillo caldera near the villages of La Paz Centro and Malpaisillo, as well as along the road N26. Field correlations were established based on the stratigraphic position, sedimentary structures, relative proportion and grain size of components (ash, pumice and lithics), and pumice characteristics (color, texture and mineralogy). In order to define the dispersal of the tephras, the apparent thickness of the deposits and the size of the largest clasts were measured (for details see supplementary methods).

\subsection{Sample preparation}

From the 150 samples collected in total, 99 samples from 41 different outcrops were selected for geochemical analysis. Where macroscopically different clast varieties were observed, subsamples have been built to cover different compositions. For each sample at least five fresh pumice lapilli were cleaned with distilled water in order to remove the attached dust and alteration rims. After drying, crushing and sieving into $>250 \mu \mathrm{m}, 250-125 \mu \mathrm{m}$ and 125-63 $\mu \mathrm{m}$ fractions, glass shards from the 125-63 $\mu \mathrm{m}$ fraction of each sample were embedded in epoxy resin (Araldite) and subsequently polished for microanalysis.

\subsection{Electron microprobe (EMP)}

EMP analyses were done with a JEOL JXA 8200 wavelength dispersive EMP at GEOMAR (Kiel, Germany) for major and minor elements following Kutterolf et al. (2011). Basic settings for conducting measurements included: (1) a measurement routine calibrated by using international standards, cross-checked by repeated measurements (every 60th singleshard measurement) of well-known natural glass standards (e.g. Lipari; Hunt and Hill, 2001), which yielded a deviation of $<0.9 \%$ for major $\left(\mathrm{SiO}_{2}, \mathrm{Al}_{2} \mathrm{O}_{3}\right)$ and $<4 \%\left(\mathrm{~K}_{2} \mathrm{O}, \mathrm{Na}_{2} \mathrm{O}, \mathrm{CaO}\right)$ as well as $<8 \%\left(\mathrm{TiO}_{2}\right.$, and $\mathrm{FeO}_{\mathrm{t}}$; $\mathrm{t}=$ total iron; $\mathrm{FeO}+\mathrm{Fe}_{2} \mathrm{O}_{3}$ ) for most minor elements (see supplementary data 3 and 4), (2) a constant accelerating voltage of $15 \mathrm{kV}$, and (3) a beam defocused to a diameter of $5 \mu \mathrm{m}$ to reduce Na-loss, and a beam current of $6 \mathrm{nA}$ for felsic glasses. All measurements were normalized to $100 \%$ on a volatile-free basis to eliminate small effects of variable post-depositional hydration and minor deviations in the electron beam focus.

3.4. Laser ablation inductively coupled plasma mass spectrometry (LA-ICPMS)

LA-ICP-MS minor and trace element measurements of glass shards were done at the University of Bern (Switzerland) using a GeoLas-Pro
2006 ArF Excimer laser system (Lambda Physik/Coherent) attached to an Elan DRC-e quadrupole mass spectrometer (Perkin Elmer). Instrument optimization strategies followed those detailed in Pettke et al. (2012). Some additional glass shards were measured at the Academia Sinica in Taipei (Taiwan) equipped with $193 \mathrm{~nm}$ excimer laser system (Photon Machines Analyte G2 laser) coupled to a high-resolution ICPMS (ThermoFinnigan Element XR) performing the analysis outlined in Kutterolf et al. (2016). Measurement reproducibilities across the entire measurement periods was $<2-7 \% 1$ SD for most elements, but uncertainties increase when measurements approach the element-specific limits of detection. Compared to T1-G in Bern and BCR-2g in Taipeh, most measured element concentrations agree to within $10 \%$ uncertainty, except for some elements, that agree within $<15 \%$ (Li, Sc, Y, Gd, Dy, Er, Tm, Lu, Yb, Tb, Ho, Ta). Concentrations and more details for both instrumentation setups as well as respective uncertainties are given in supplementary methods and supplementary datas 3 and 4).

\section{5. ${ }^{40} \mathrm{Ar} /{ }^{39} \mathrm{Ar}$ dating}

Two samples, representing the lower and upper part of the Malpaisillo tephra succession, were selected for radiometric dating, which was performed at Lamont-Doherty Earth Observatory (U.S.A.). Measured isotope data were corrected for background contributions based on frequent measurements of the blanks (every three to four samples), mass discrimination based on average measurements of air aliquots through the duration of the sample disk run (every 12 samples), and nuclear interferences based on values characteristic of this reactor (values taken from Dalrymple et al., 1981). Detailed information is given in supplementary methods and supplementary Fig. 2.

\subsection{Determination of eruptive volumes and masses}

Only for Tolapa Fall the isopach data have been sufficient to apply the methods of Pyle (1989) and Fierstein and Nathenson (1992), to determine the total tephra volume expressed in cubic kilometers. In other cases data for the thickness and abundance of distal eruptive products were sparse and only rough minimum estimates of eruptive volumes were performed following the method after Legros (2000) modified by Kutterolf et al. (2016, 2018) and Schindlbeck et al. (2015, 2016b, 2018a). More details and a discussion explaining the reasons to use Legros's model is given in the supplementary methods. Tephra volumes were converted to erupted magma masses and the respective dense rock equivalent volume (DRE $\mathrm{km}^{3}$ ) applying the method of Kutterolf et al. (2007, 2008b). For one eruption cross-range half-widths of reconstructed MP-isopleths were compared with numeric eruption column models of Carey and Sparks (1986) to derive estimations of the eruption column height.

\subsection{Correlations and deposit classification}

All deposits are described in detail using structural and textural characteristics like for instance sorting, gradation, bedding, and component distribution. To simplify reading, the interpretive terms "flow deposit", "ignimbrite", "surge", and "fallout" are already used in the description of the deposits using definitions and classifications given in the literature (e.g. Schmincke, 2004; Fisher and Schmincke, 1984; Walker, 1983; Freundt and Bursik, 1998) that are explained in more detail in the supplementary methods. Since the structural and textural features in the deposits depend strongly on how the eruption proceeded and the flow conditions changed (e.g. single versus multiple pyroclastic flows, partial versus complete eruption column collapse, topography, distance from vent, recurrence rate of multiple pyroclastic flows, density of flows), many transitional features between the characteristic end member deposits are possible and observed.

Stratigraphic correlations of the Malpaisillo deposits (Figs. 5 and 6) are based first on field observations and clast characteristics (e.g. 


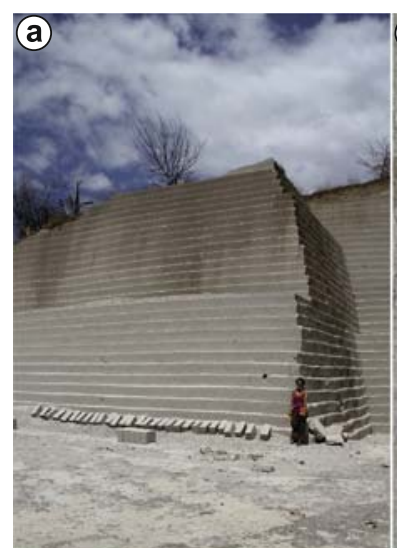

(d)
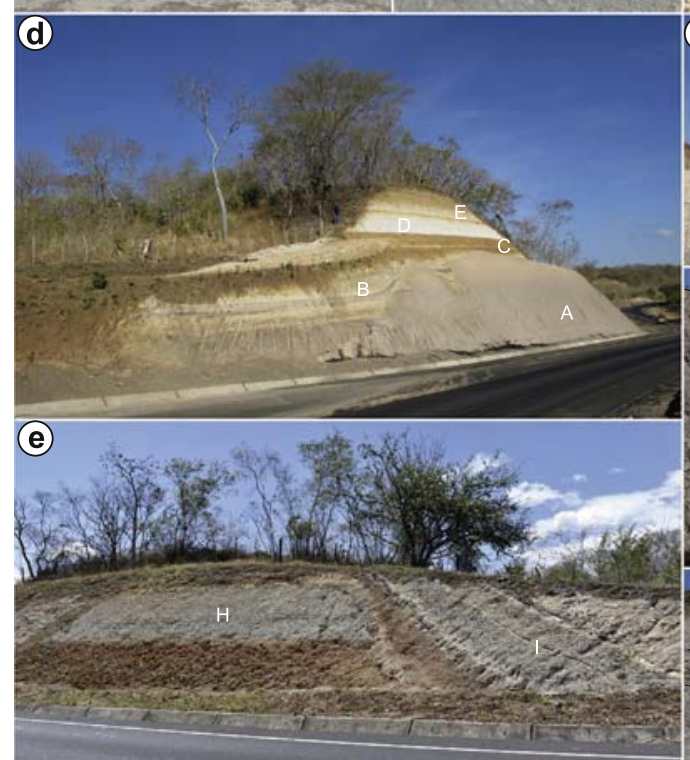

(f)

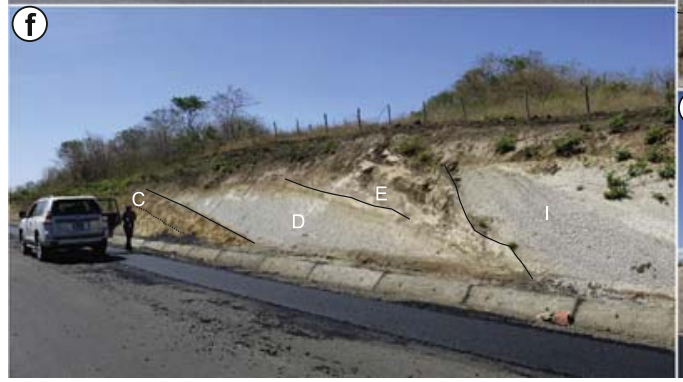

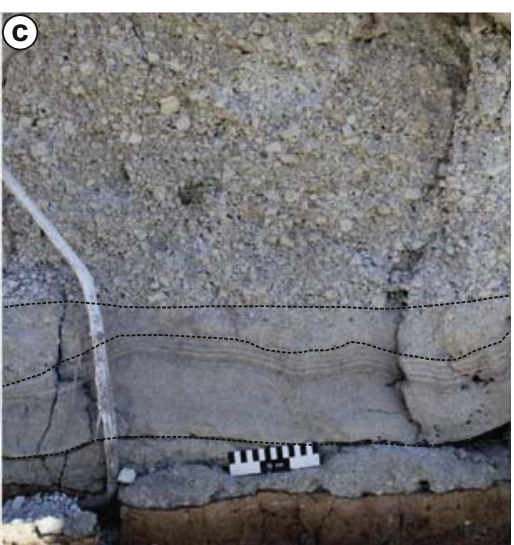

(a)

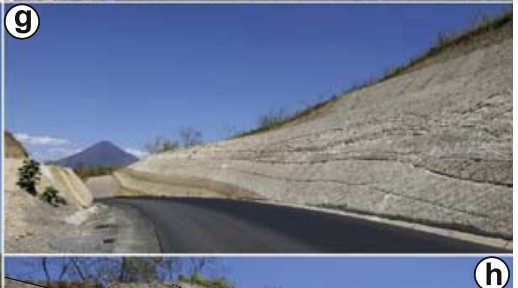

(h)
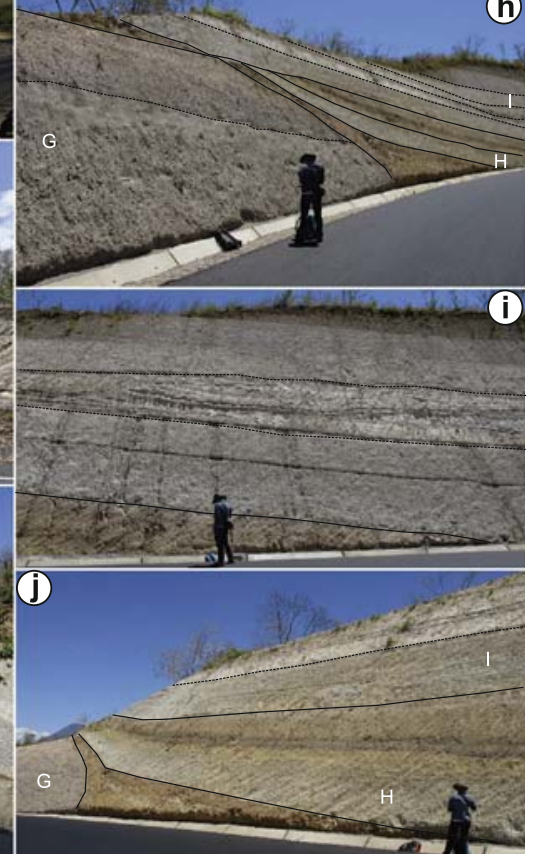

Fig. 3. Photographs showing tephra sequences of the Malpaisillo/Monte Galán calderas. Tephra units are given in capital letters. a) Location L33/13 at La Paz Centro where the ignimbrites of Tolapa Tephra are quarried for bricks. b) Close up of a) showing the poorly-sorted, pumice-rich texture of the Tolapa Ignimbrite. c) Lower part of Tolapa Tephra at location L22/13, west of the caldera, with initial fall and surge deposits continuing into massive pumice fallout. d) Lower part of the tephra sequence at L1/15 showing La Paz Centro Tephra [A], Punta de Plancha Tephra [B], Lower Chibola Tephra [C], Guacucal Tephra [D], Upper Chibola Tephra [E], the involved paleosols, and erosive unconformities. e) Outcrop L3/15 showing the unconformity between Miralago fallout Tephra [H] and Tolapa Tephra basal sequence [I]. f) Outcrop L3/15 showing the tephra units below the unconformity that separates Upper Chibola Tephra [E] and Tolapa Tephra basal sequence [I]. g) Tephra sequence at new road cuts of outcrop location L5/15. h) Outcrop location L5/15 showing unconformities between Sabanettas ignimbrites [G], Miralago fallout [H], and the Tolapa Tephra [I]. i) Close up of Tolapa Tephra with the two thick fallout layers at the base, the $>2 \mathrm{~m}$ thick surge deposit in between, and the ignimbrites on top. j) Outcrop location L5/15 showing a close up of Sabanettas ignimbrites [G], Miralago fallout [H], and the Tolapa fallout and surge deposits [I].

texture, mineralogy), and are cross-checked against compositional signatures or entirely based on the latter if the other parameters are not sufficient. It turned out that the major element geochemistry of the deposits, which defines very distinct geochemical groups (Figs. 7, 8), is the most helpful tool to correlate the outcrops, verify the overall stratigraphy, and compile a composed stratigraphic column for the Malpaisillo Formation. In the compiled stratigraphic column (Fig. 6) individual stratigraphic Units are separated from each other by paleosols; hence, individual stratigraphic units are interpreted as individual eruptions. Depositional variations within each eruption are called subunits.

\section{Lithology, stratigraphy and composition of the Malpaisillo Formation}

\subsection{General introduction}

The tephra sequences belonging to the Malpaisillo Formation include mainly pyroclastic flow and fallout deposits, as well as minor surge deposits. Whereas the fallouts are distributed radially to the west of the caldera, the most proximal flow deposits are mainly directed toward La Paz Centro in the southwest but also within the vicinity of the 
(a)
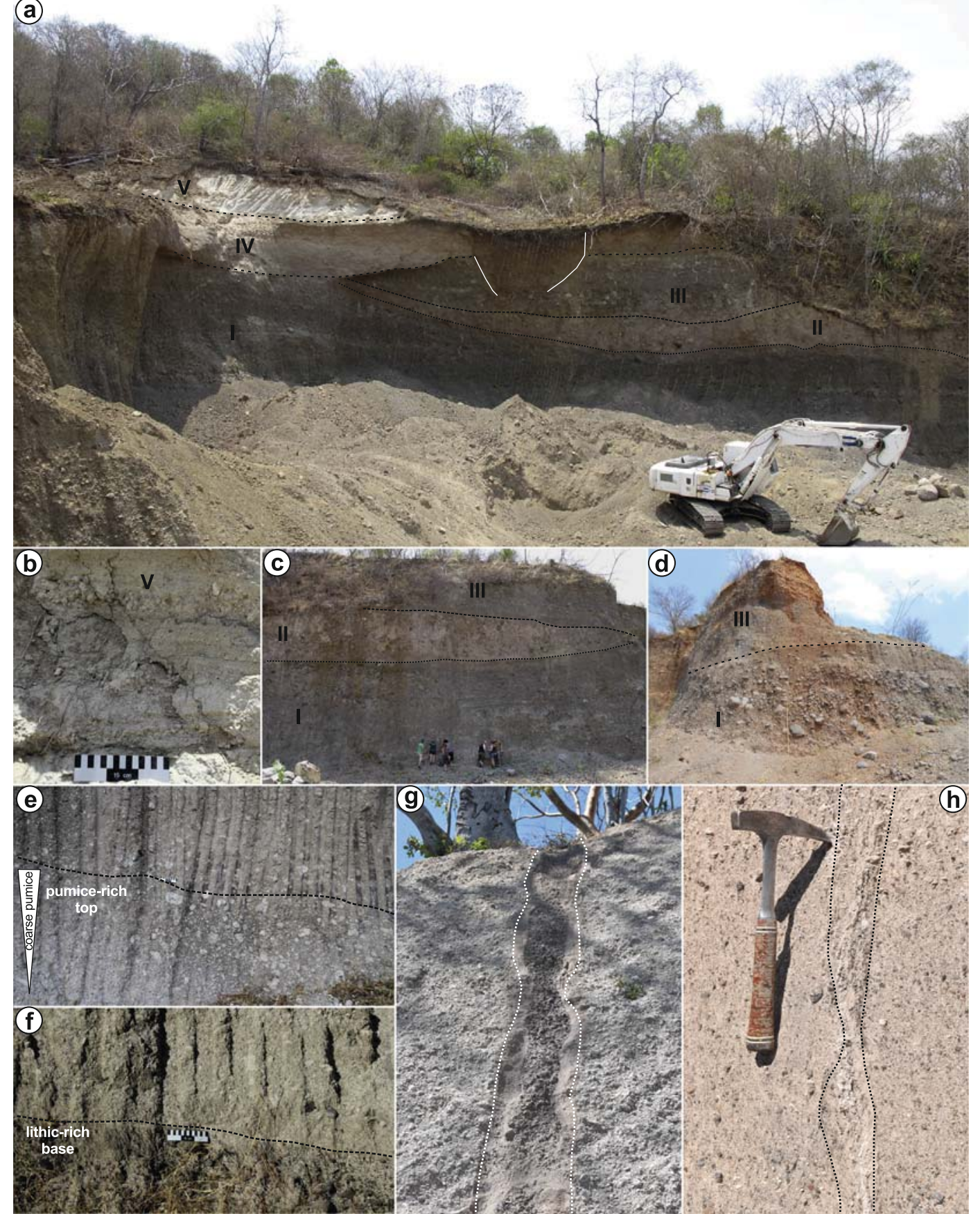

Fig. 4. a) Overview of the outcrop L13/13 with La Fuente Tephra (I to V), consisting of grey very lithic-rich ignimbrites (I, III), brownish ignimbrites rich in ash matrix (II, IV), as well as white ash and surge deposits of Sabanettas Tephra (V). b) Close up of the Sabanettas Tephra at L13/13. c) + d) Close up of three flow units in La Fuente Tephra (I to III), with I being characterized as lag breccia, II pinching out in c) and being absent in d). e) Details of the outcrop L42/13 showing the contact between two ignimbrite flow units, marked by a coarsening-up and enrichment of the pumice clasts. f) Lower part of the lowermost flow unit in outcrop L42/13 showing lithic enrichment at its base. g) Degassing pipe in La Paz Centro ignimbrite found in outcrop location L5/15 where fine matrix was removed and lithic lapilli remained. h) Degassing pipe in Sabanettas ignimbrite found in outcrop location L6/15.

entire caldera structures. Surge deposits are only minor and locally present.

The up to $30 \mathrm{~m}$ thick piles of pyroclastic deposits are interrupted by eleven paleosols and five unconformities, defining a total of at least 12 major stratigraphic units. Each of them is composed of fall or flow deposits or both, and represents one eruption with distinct chemical glass composition/grouping (Fig. 6). Some of the more complex eruptions include subphases characterized by deposits with more than one type of emplacement but showing no signs of a longer break in the eruption and belong to the same chemical group of juvenile glasses. The basal parts of proximal flow deposits are often not exposed. Stratigraphic profiles and descriptions of each outcrop are given in supplementary Fig. 1 and supplementary data 2.

The juvenile clasts of the pumice and ignimbrite layers are mainly composed of highly vesicular, whitish pumice clasts, whereas about $1 \mathrm{vol} \%$ of the juvenile fraction is represented by pumice clasts with "streaky patterns" that show a more silvery or dark color with laminar mixtures of vesicular and more glassy parts. Andesitic to dacitic, fresh and hydrothermally altered lithics are generally small and scarce ( $10 \mathrm{~mm}$, up to $15 \mathrm{wt} \%$ ) but can be larger and strongly enriched in some beds and layers. Phenocrysts in pumices are often arranged in clusters 

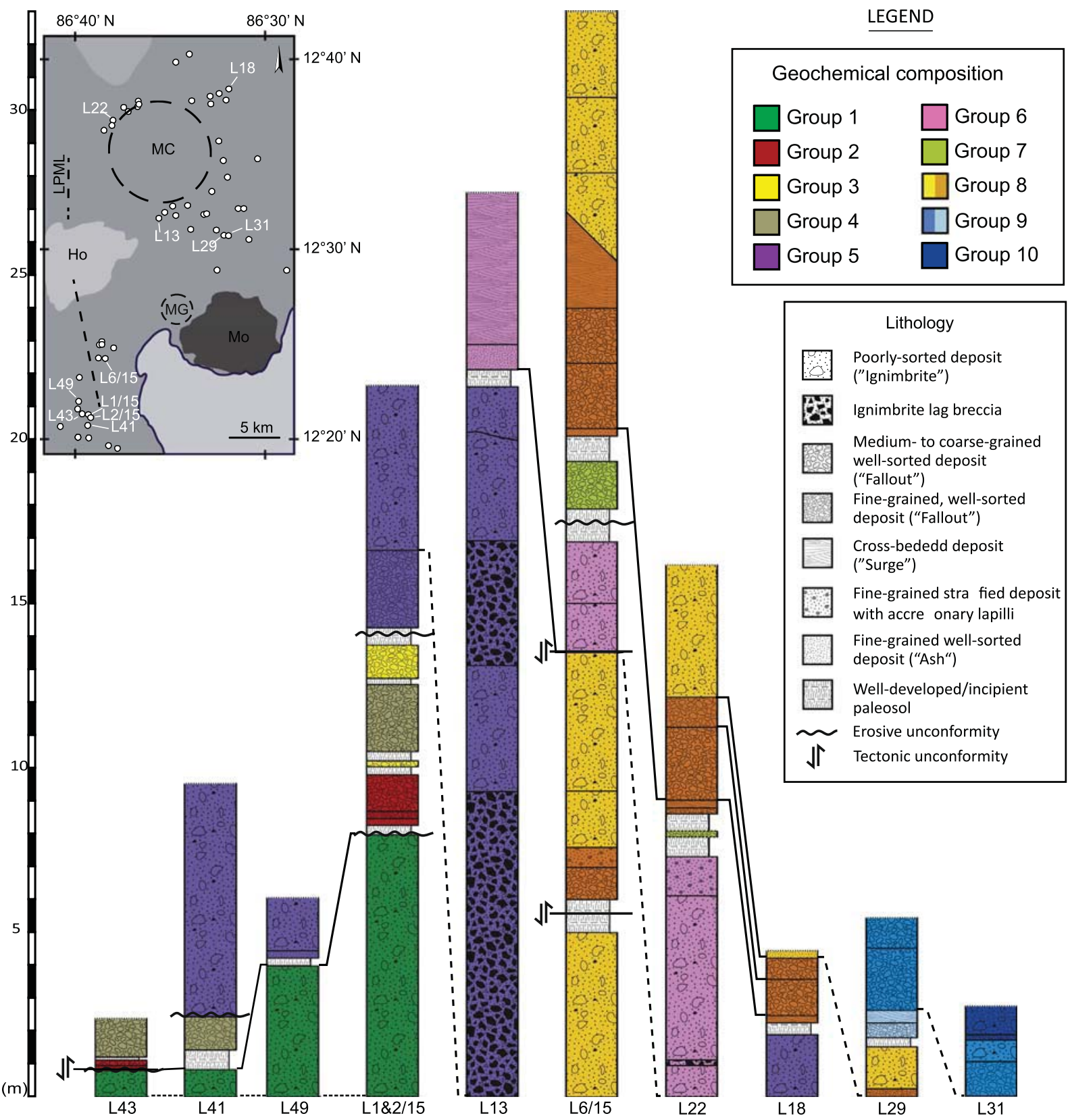

Fig. 5. Stratigraphic correlations of the Malpaisillo/Monte Galán deposits based on the best-exposed outcrops. The colors corresponding to the stratigraphic units and chemical groups are superimposed onto the stratigraphic section in order to facilitate the correlations. Insert map: location of the outcrops with respect to the Malpaisillo and Monte Galán calderas (MC, MG) as well as the surrounding relief (in dark grey), including the volcanoes El Hoyo (Ho), Momotombo (Mo) and the La Paz Centro - Malpaisillo Lineament (LPML).

and contain plagioclase ( $\mathrm{pl})$, pyroxene (px), titanomagnetite, and minor quartz (qtz).

The highly evolved juvenile compositions range between mediumto high-K rhyolites $\left(\mathrm{SiO}_{2}=69.5-74.9 \mathrm{wt} \%, \mathrm{~K}_{2} \mathrm{O}+\mathrm{Na}_{2} \mathrm{O}=6.8-8.2 \mathrm{wt}\right.$ $\%$; $\left.\mathrm{K}_{2} \mathrm{O}=2.3-3.9 \mathrm{wt} \%\right)$ with the exception of the Punta de Plancha Tephra (outcrops L43/13 and L1/15), where dacitic compositions $\left(\mathrm{SiO}_{2}=\sim 65.0 \mathrm{wt} \%, \mathrm{~K}_{2} \mathrm{O}+\mathrm{Na}_{2} \mathrm{O}=\sim 6-7 \mathrm{wt} \%\right)$ prevail (Fig. 7). Observed obsidian or streaky pumices do not differ in composition from the other juveniles of their host layers. Starting with the oldest one we will describe in the following each of the twelve stratigraphic units that are separated by paleosols or unconformities regarding their characteristic appearance in the outcrop and composition of juveniles.

\subsubsection{La Paz Centro Tephra (LPT)}

La Paz Centro Tephra (LPT) is the lowermost tephrostratigraphic Unit I and its basal contact is not visible in the outcrops. It is composed of at least two poorly-sorted, greyish-pink, ignimbrite flow units, outcropping at five deeply incised locations situated $\sim 20 \mathrm{~km}$ south of the caldera rim and exceeding thicknesses of at least 80 to $>800 \mathrm{~cm}$ thickness (Fig. 2, 3D, 5; supplementary datas 1,2 ). LPT has been cut by subsequent tectonic and erosive events after emplacement (Figs. 5, 6). The ignimbrite consists of a white to pale brown to pinkish and grey ash matrix ( $70 \mathrm{vol} \%), \sim 20 \%$ of rounded, greyish/silver and beige, highly microvesicular/fibrous, medium to coarse, pumice lapilli with mineral nests of px, qtz, pl, and $\sim 10 \mathrm{vol} \%$ of basaltic to andesitic lithic clasts $(\varnothing 1-5 \mathrm{~cm})$. Some scattered, well-rounded pumice blocks with diameter up to $15 \mathrm{~cm}$ occur in the upper part of both flow units whereas matrix and lithic content increase toward the bases (e.g. Fig. 4E, F). Occasionally lithic-filled lapilli-pipes can be identified that continue across the flow-unit boundaries (Fig. 4H).

Juvenile clasts are characterized by a $\mathrm{K}_{2} \mathrm{O}$-enriched rhyolithic composition (Fig. 7; $\mathrm{SiO}_{2}=73.3 \mathrm{wt} \%, \mathrm{~K}_{2} \mathrm{O}=3.5 \mathrm{wt} \%$ ) that is similar in most major element concentrations to the stratigraphically higher 


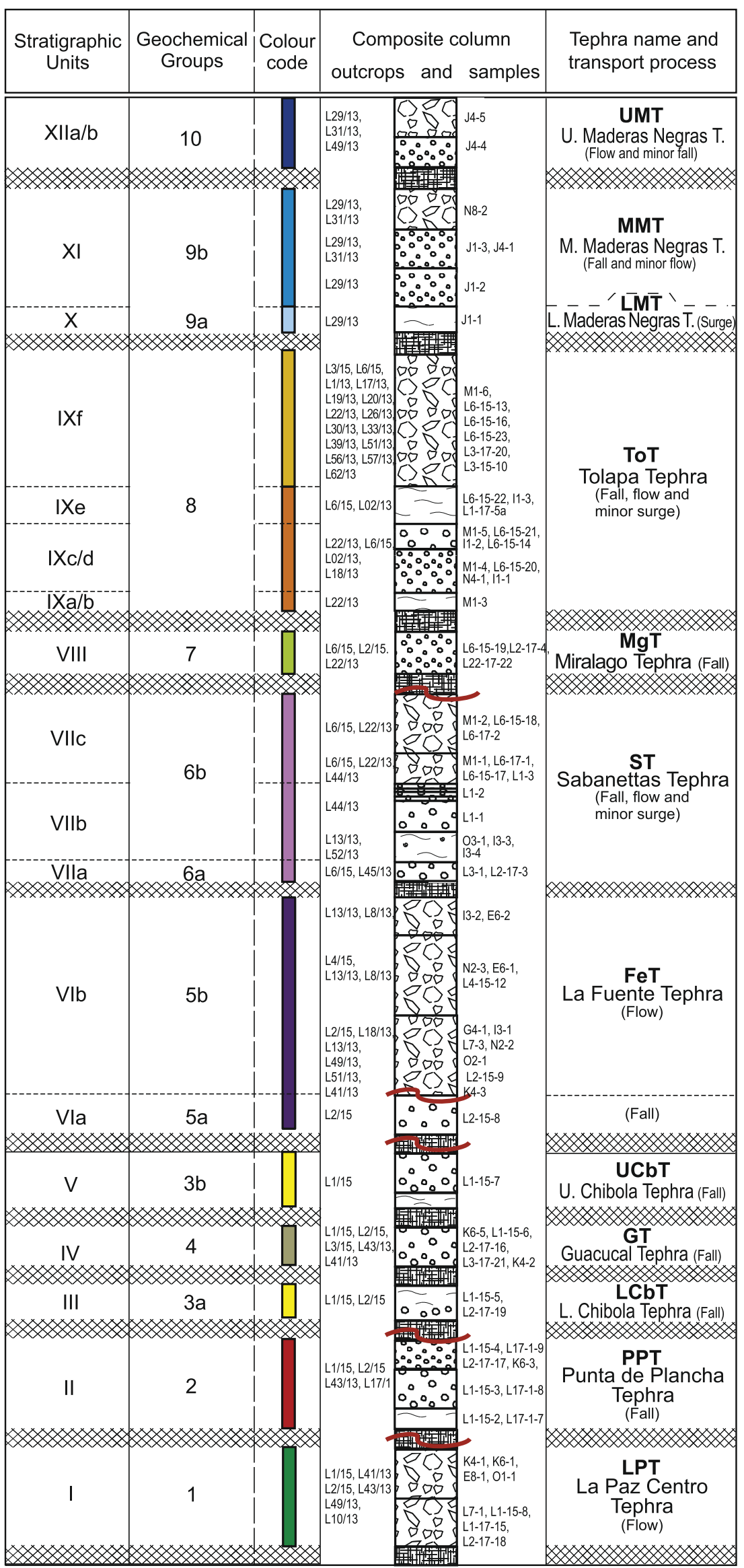

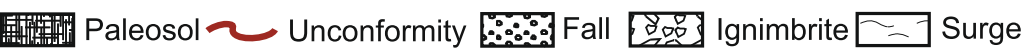


Guacucal Tephra (GT) but differs in $\mathrm{FeO}_{\mathrm{t}}$ and $\mathrm{CaO}$ (Fig. 8, supplementary Fig. 3, supplementary data 3). Their similar chemical compositions indicate a close relation of their magmatic systems. Due to lower Ba and higher $\mathrm{Rb}$ concentrations flow units of LPT show similarly low Ba/La and $\mathrm{Ba} / \mathrm{Rb}$ ratios like nearly all other Malpaisillo units (Fig. 9; supplementary data 3 ).

\subsubsection{Punta de Plancha Tephra (PPT)}

The second oldest tephrostratigraphic Unit II, the Punta de Plancha Tephra (PPT), encompasses three subunits composed of fall and flow deposits. It is overlying LPT on top of a $70 \mathrm{~cm}$ thick paleosol. Its occurrence is limited to outcrops L1/15, L2/15, L17/1, and L43/13 (Figs. 2, 5, 6; supplementary Fig. 1; supplementary datas 1, 2). Subunit Ila outcrops at L1/15 with thickness of $\sim 22 \mathrm{~cm}$ and appears as a thin grey, poorlysorted coarse ash (L1/15). Subunit IIb is composed of 17 to $20 \mathrm{~cm}$ thick fallout of fine-grained lapilli and numerous mm-sized lithics. The microvesicular pumices are white, dark grey, silver and brownish altered and contain px and pl. A beige, $165 \mathrm{~cm}$ thick fallout of medium-grained, highly vesicular, grey pumice lapilli (brownish if altered) with large elongated vesicles and $\mathrm{px}, \mathrm{pl}$, and qtz phenocrysts characterizes subunit IIc and shows a cm-thick pink ash layer at the base. More whitish pumice lapilli are mixed in the overall lapilli inventory.

Unit II is characterized by the most mafic, overall dacitic composition, of the entire Malpaisillo Formation (Fig. 7), showing the lowest alkali (6.3-6.9 wt\%) and silica (64-66 wt\%) contents in the diagram after Le Maitre (1989). It is accompanied by the highest $\mathrm{Al}_{2} \mathrm{O}_{3}, \mathrm{FeO}_{\mathrm{t}}, \mathrm{MgO}$, $\mathrm{TiO}_{2}$, and $\mathrm{CaO}$ contents found in all investigated deposits (Fig. 8). Unit II deposits are therefore compositionally clearly distinguishable from all other tephras. Trace element ratios confirm this (e.g. lowest $\mathrm{Ba} / \mathrm{Nb}$ and $\mathrm{Ba} / \mathrm{La}$ ratios in Malpaisillo Formation; Fig. 9). Major elements of subunits differ slightly due to the compositional range between white to grey pumices (supplementary data 3 ); nevertheless, the uniform trace element ratios (e.g. $\mathrm{Ba} / \mathrm{Nb}, \mathrm{Ba} / \mathrm{La}, \mathrm{Zr} / \mathrm{Nb}, \mathrm{Sm} / \mathrm{Nd}, \mathrm{Dy} / \mathrm{Lu}$ ) underline their origin from the same magma (Fig. 9).

\subsubsection{Lower Chibola Tephra (LCbT), Guacucal Tephra (GT), Upper Chibola Tephra (UCbT)}

Three pure fallout deposits, bounded by paleosols at outcrop L1/15, represent stratigraphic units III, IV, and V. These are the Upper and Lower Chibola Tephra with the Guacucal Tephra intercalated in between (Figs. 5, 6). GT and LCbT can also be observed at L2/15; GT also at L43/13 and L3/15 (Fig. 2; supplementary Fig. 1; supplementary datas 1,2$)$.

The LCbT (Unit III) represents a thin, $21 \mathrm{~cm}$ thick layer of reverselygraded massive fine to coarse lapilli that is eroded at the top. It consists of white to beige pumice clasts ( $\mathrm{MP}=5 \mathrm{~cm}$ ) and some $(<5 \mathrm{vol} \%)$ hydrothermal altered lithics. The upper layer (UCbT, Unit V) is a $>1$ m thick, vaguely stratified coarse pumice lapilli layer with hydrothermal altered lithics ( $<3$ vol\%) and with a $\sim 15 \mathrm{~cm}$ thick, fine white ash at the base that contains accretionary lapilli. The white, highly vesicular pumices $(\mathrm{MP}=6 \mathrm{~cm})$ contain pl, px, and Fe/Ti-oxides. Guacucal Tephra (GT, Unit IV), in between, is a massive and well-sorted medium to coarse pumice fallout layer with a thickness of $\sim 120 \mathrm{~cm}$ (L43/13, L5/15; MP = $10 \mathrm{~cm})$ to $>200 \mathrm{~cm}(\mathrm{~L} 1 / 15 ; \mathrm{MP}: 8 \mathrm{~cm})$ that contains only a few hydrothermal altered and fresh lithics ( $<3 \mathrm{vol} \%$ ). The microvesicular pumices are white, dark grey, silver and sometimes brownish altered, have large elongated vesicles and contain px and pl. At the base a $\sim 5$ (L1/15) to 17 (L43/ 13) $\mathrm{cm}$ thick coarse ash and fine lapilli layer is exposed. Rare, grey and moderately vesicular pumices occur interspersed throughout GT.

The Chibola Tephras (Unit III and V) have a similar chemical composition. All major element concentrations show close relationship between rhyolitic LCbT and UCbT and also to the younger deposits of the
Malpaisillo Formation (Figs. 7, 8). Compared to the other investigated tephras they contain moderate $\mathrm{K}_{2} \mathrm{O}\left(3.1-3.2 \mathrm{wt} \%\right.$ ) and $\mathrm{SiO}_{2}$ (72.1-72.6 wt\%) concentrations (Figs. 7, 8; supplementary data 3). Trace element concentrations are similar between LCbT and UCbT but show often significant differences with respect to the younger tephra units following in the tephra sequence (lower $\mathrm{Ba} / \mathrm{La}, \mathrm{Ba} / \mathrm{Nb}, \mathrm{Zr} / \mathrm{Nb}$, and $\mathrm{Ba} / \mathrm{Zr}$ ratios; Fig. 9). The rhyolitic GT (Figs. 7, 8) can clearly be distinguished from the other units by its chemical composition through its high $\mathrm{K}_{2} \mathrm{O}$ (3.45 wt\%) contents as well as its intermediate $\mathrm{CaO}, \mathrm{FeO}_{\mathrm{t}}$, and $\mathrm{MgO}$ concentrations $\left(\mathrm{CaO}=1.76\right.$ wt\%, $\mathrm{FeO}_{\mathrm{t}}: \sim 2.2, \mathrm{MgO}=$ $0.34-0.35 \mathrm{wt} \%$ ) and the low $\mathrm{TiO}_{2}(0.26 \mathrm{wt} \%)$ content (Fig. 8). Trace element concentrations and ratios are distinctively different from the other Malpaisillo tephra units like observed in the major elements (Fig. 9; supplementary data 3 ).

\subsubsection{La Fuente Tephra (FeT)}

Unit VI, the La Fuente Tephra (FeT), is observed radially a few km around the caldera and as far as $23 \mathrm{~km}$ to the south of the caldera in seven outcrops (Figs. 2, 5, 6; supplementary Fig. 1; supplementary datas 1,2 ). At the proximal type location (L13/13, Fig. 3), three poorly-sorted ignimbrite flow units are distinguished (respectively $>13 \mathrm{~m}, 7 \mathrm{~m}$ and $1.5 \mathrm{~m}$ thickness; VIb) and separated by unconformities, while in medial distances, $\sim 20 \mathrm{~km}$ further to the south, a $2.30 \mathrm{~m}$ thick fallout unit (Vla) and a $>5 \mathrm{~m}$ thick ignimbrite ( Vlb) are exposed.

Subunit Vla is composed of a massive, thick $(<230 \mathrm{~cm})$, well-sorted, white pumice fallout layer. Angular pumice clasts are coarse (MP = $6 \mathrm{~cm}$ ) and contain glass nests with a phenocryst assemblage (qtz, pl, $\mathrm{px}$, and bi) characteristic for all subunits.

In the proximal type location $\mathrm{L} 13 / 13(\sim 5 \mathrm{~km}$ from the caldera center) the basal ignimbrite/flow Unit VIb shows in the first $\sim 9 \mathrm{~m}$ a clastsupported, very lithic-rich ( $>65 \mathrm{vol} \%$ ), thick bed. Lithics are up to block-sized $(\sim 50 \mathrm{~cm} \emptyset)$ and in part hydrothermally altered. They are enriched before a topographic ridge acting as a morphological barrier that creates a hydraulic jump, meeting the definition of a proximal ignimbrite lag breccia (e.g. Druitt, 1985). The pinkish white ash matrix ( $20 \mathrm{vol} \%$ ) contains some (5-10 vol\%) rounded, white and highly vesicular as well as grey and moderately vesicular fine- to medium-grained pumice lapilli. The upper four meters of the ignimbrite/flow unit is a matrix-supported bed that is dominated ( $\sim 90 \mathrm{vol} \%)$ by pinkish white (brownish when altered) ash matrix and contains a few highly vesicular fibrous streaky medium-grained pumice lapilli that are enriched in a horizon in the uppermost meter. The following middle ignimbrite/ flow unit is a $\sim 4 \mathrm{~m}$ thick ash matrix-supported bed that shows reduced grain sizes. The base is enriched in $\mathrm{cm}$ - to dm-sized mostly fresh lithics ( 65 vol\%) with few fine-grained, highly vesicular, fibrous pumice lapilli ( $<5 \mathrm{vol} \%$ ). The upper $\sim 3.5 \mathrm{~m}$ thick beige part contains ash with $\mathrm{mm}-$ sized obsidian clasts, and 5 vol\% of rounded grey, moderatelyvesicular, fine pumice lapilli with subspherical microvesicle, mm-sized lithics ( 7 vol\%), and a lithic pebble-rich base. The uppermost $\sim 1.60 \mathrm{~m}$ thick ignimbrite/flow has a thin, lithic-rich, basal horizon, and the main body is characterized by an ashy matrix ( $90 \mathrm{vol} \%)$ and few, rounded fine pumice lapilli.

Juvenile clasts of all subunits are characterized by comparable rhyolithic compositions that are slightly enriched in $\mathrm{K}_{2} \mathrm{O}$ compared to other tephras with the same $\mathrm{SiO}_{2}$ content (Fig. 7; $\mathrm{SiO}_{2}=72.0-72.4 \mathrm{wt}$ $\%, \mathrm{~K}_{2} \mathrm{O}=3.3-3.4 \mathrm{wt} \%$, whereas $\mathrm{Al}_{2} \mathrm{O}_{3}, \mathrm{CaO}, \mathrm{TiO}_{2}$ and $\mathrm{MgO}$ concentrations are lower (Fig. 8). Subunit Vla and VIb can only be distinguished by the lower MgO content of Vla and more variable trace element concentrations and ratios of Vla (Figs. 8, 9; supplementary data 3). The geochemistry of FeT is generally represented by intermediate LILE concentrations, slightly higher than the subsequent tephras at the 

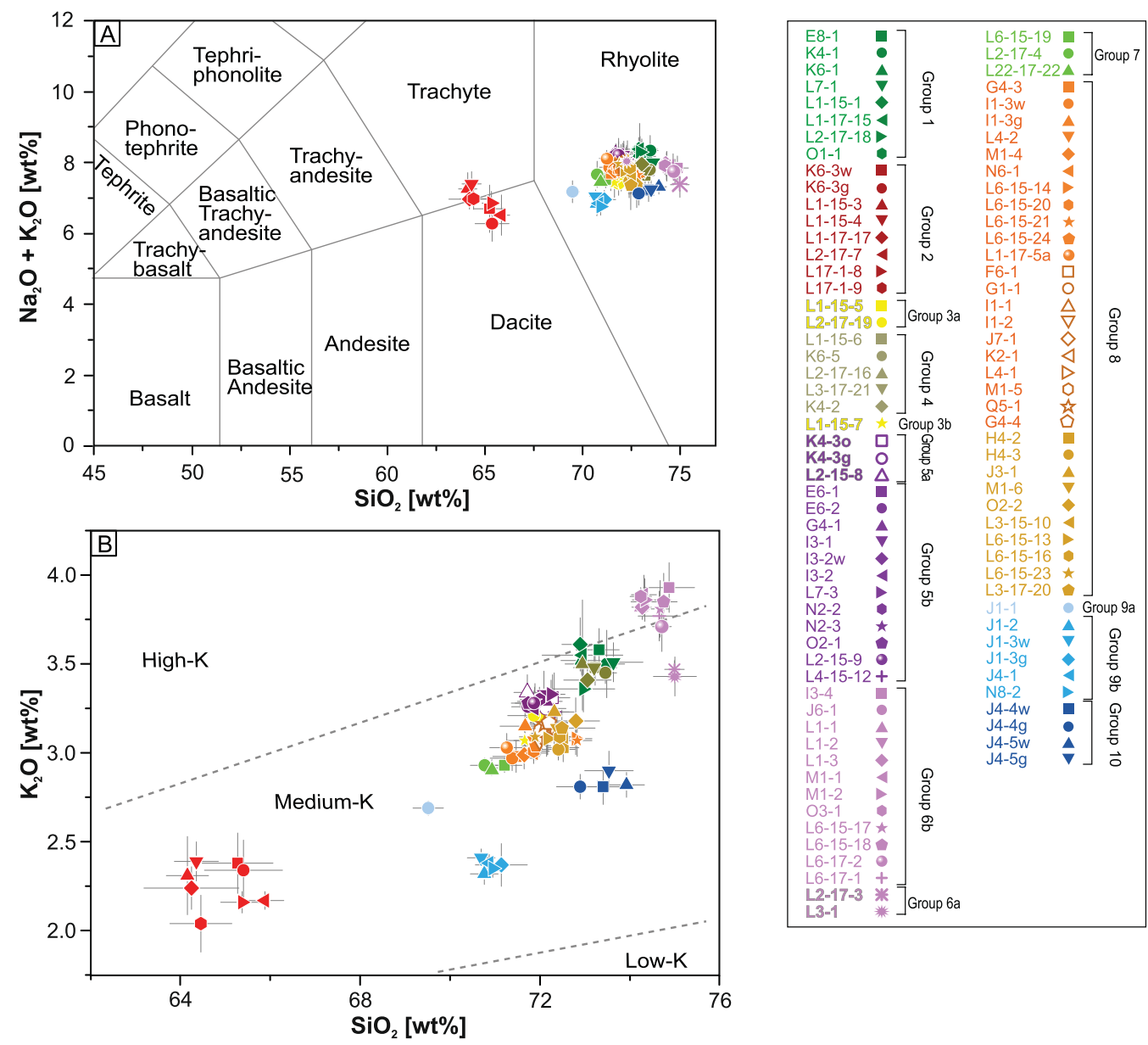

Fig. 7. Matrix-glass compositional ranges of Malpaisillo/Monte Galán tephras (normalized to anhydrous compositions). A) Total alkali versus silica plot to indicate compositional variability in Malpaisillo/Monte Galán tephras and to discriminate between volcanic rock classes after Le Maitre (1989). B) The analyzed glass shards cluster into major compositional groups describing High-K, Medium-K, and Low-K volcanic rocks indicating the major differences within the investigated Malpaisillo/Monte Galán Formation. Symbols are averages of all analyses made for each tephra. Compositional variations per analyzed tephra sample are shown with grey bars. The colors, given in the legend, represent the geochemical groups and the individual tephra unit (color-code also in Fig. 6), with the exception of the Lower and Upper Chibola Tephra that inhabits the same compositional signal and therefore the same geochemical group (yellow).

same content of $\mathrm{SiO}_{2}$ and can easily be distinguished using trace element concentrations and their ratios (Fig. 9).

Schindlbeck et al. (2016a) correlated compositionally a 380 ka old (determined by sedimentation rates), $2 \mathrm{~cm}$ thick, ash layer (G2), $320 \mathrm{~km}$ to the south of the Malpaisillo Caldera, offshore Nicoya peninsula (Costa Rica), unambiguously with the FeT, which drastically increases its distribution.

\subsubsection{Sabanettas Tephra (ST)}

Three subunits belong to the Sabanettas Tephra (Unit VII) in at least eight outcrops around the caldera (Figs. 2, 5, 6; supplementary datas 1, 2, 3; supplementary Fig. 1; supplementary datas 1,2). A basal massive $\sim 70 \mathrm{~cm}$ thick white ash that contains accretionary lapilli (L13/13) grades into a fine-grained up to $4 \mathrm{~m}$ thick white to beige surge deposit with laminated lenses of fine-ash and medium-grained pumice lapilli (subunit VIIa; L50/13, L52/13). A pile (subunit VIIb) of normal-graded, fine to medium-grained, thin pumice fall deposits (L50/13, L52/13) up to $4 \mathrm{~m}$ thick (L44/13) follows on top of subunit VIla, overlain by two several meters thick ignimbrite flow units (subunit VIIIc; L6/15, L52/13,
L44/13) that have a pumice-rich horizon in the upper part of the lower flow unit and a lithic enrichment in the basal part of the upper flow unit. The ignimbrite, in places $>5 \mathrm{~m}$ thick, is rich in a fine- to coarse-grained, pinkish ash matrix and also shows lithic-rich lapilli pipes (Fig. 4H). Generally, highly vesicular, silver pumice lapilli, containing large elongated vesicles, occur in all deposits. Pumice lapilli have moderate amounts of phenocrysts (10-20 vol\%; px, pl, qtz) concentrated in crystal nests. The ash matrix of the ignimbrite contains the same amount and types of minerals and also minor amounts of mmsized lithic fragments (<vol5\%).

Overall the ash matrix and the pumice lapilli represent the most evolved, high-K, silica-rich, rhyolitic composition of the Malpaisillo Formation (Fig. 7; $\mathrm{SiO}_{2}=74.26-74.89$ wt\%, $\mathrm{K}_{2} \mathrm{O}=3.82-3.93 \mathrm{wt} \%$ ) with the basal fallouts (samples L3/1, L17/3) having slightly higher $\mathrm{SiO}_{2}$ and less $\mathrm{K}_{2} \mathrm{O}\left(\mathrm{SiO}_{2}=75.01 \mathrm{wt} \%, \mathrm{~K}_{2} \mathrm{O}=3.45 \mathrm{wt} \%\right)$. Consequently, $\mathrm{CaO}$, $\mathrm{MgO}$, and $\mathrm{TiO}_{2}$ contents are low, whereas the $\mathrm{FeO}_{\mathrm{t}}$ concentration is the lowest found in the Malpaisillo tephras $\left(\mathrm{FeO}_{\mathrm{t}}=1.77-1.95 \mathrm{wt} \%\right.$; Fig. 8, supplementary data 3 ). Additionally, discrimination from the other tephras is facilitated by the highest HFSE (e.g. Th $=3.0-3.6 \mathrm{ppm}$ ) and

Fig. 8. Major element glass shard compositions of Malpaisillo/Monte Galán tephra units in different discrimination diagrams indicating the compositional differences of each tephra unit. Each analyzed sample, normalized to anhydrous compositions, is plotted in the diagrams. Symbols are averages of all analyses made for each tephra. Compositional variations per analyzed tephra sample are shown with grey bars. Colors represent the geochemical groups (framed by dotted lines in the legend) and also the stratigraphic units (illustrated in Fig. 6) with the exception of the Chibola Tephras, see caption and legend of Fig. 7. Additional diagrams are given in supplementary Fig. 3. 

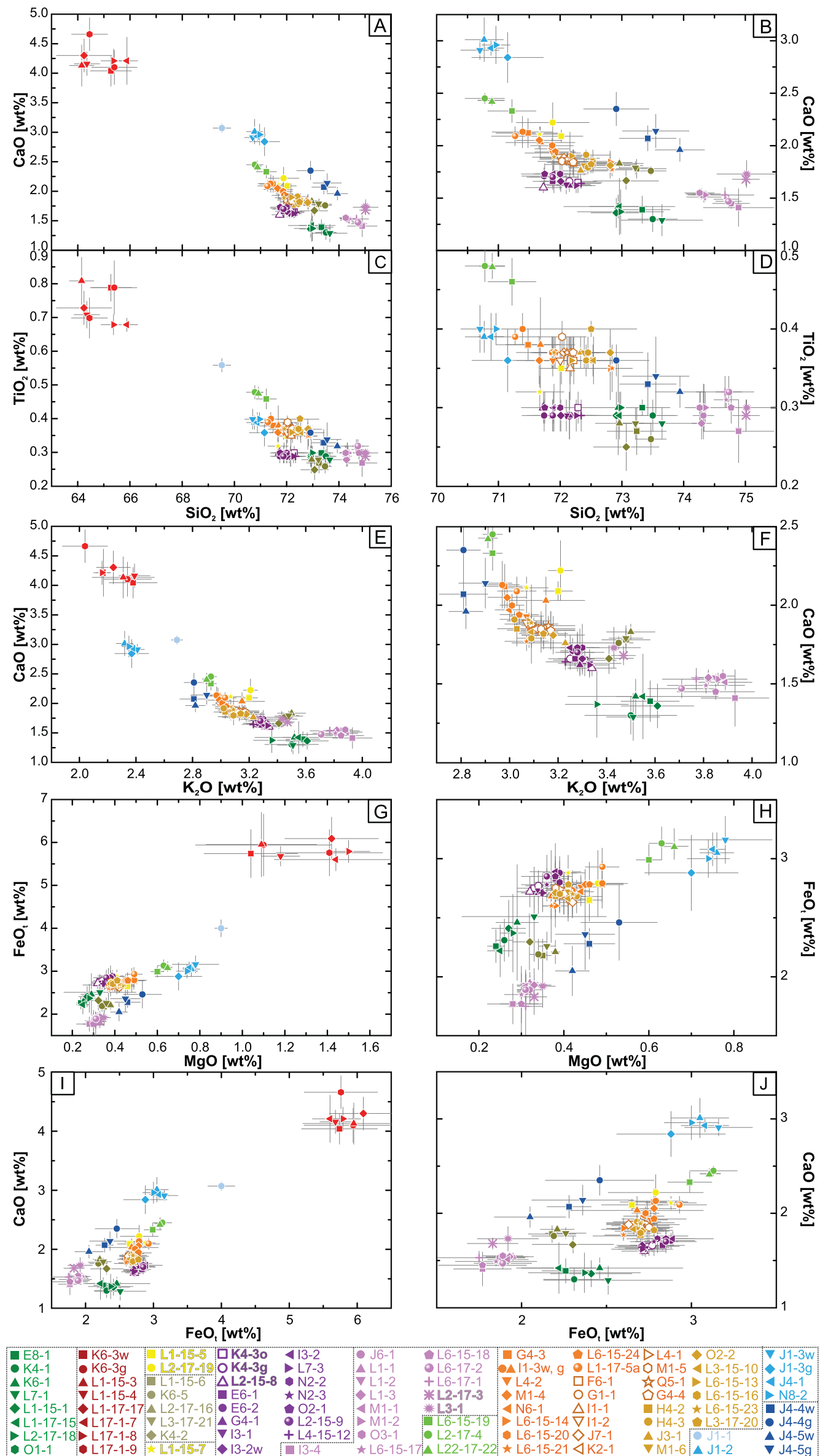
LILE $(\mathrm{Rb}=61-77 \mathrm{ppm})$ concentrations. The ratios of $\mathrm{Ba} / \mathrm{Rb}(23.1-24.5)$ and $\mathrm{Ce} / \mathrm{Hf}(4.5-5.3)$ correspond to the lowest, whereas $\mathrm{Rb} / \mathrm{La} \mathrm{(5.2-5.7)}$ and $\mathrm{K} / \mathrm{La}(0.23-0.25)$ ratios correspond to the highest values within the Malpaisillo Formation (Fig. 9, supplementary data 3).

\subsubsection{Miralago Tephra (MgT)}

The Miralago Tephra (Unit VIII) is observed in the southern outcrop L6/15 where it represents a yellow-beige $~ 155 \mathrm{~cm}$ thick, at the top partly erosive displaced, vaguely stratified, well-sorted, fine to medium pumice lapilli ( $\mathrm{MP}=5 \mathrm{~cm}$ ) layer that shows normal gradation and enrichment of angular, mm- to half-cm-sized obsidian clasts in the uppermost $10 \mathrm{~cm}$ of the fallout (Figs. 2, 5, 6; supplementary Fig. 1; supplementary datas 1, 2). At the eastern outcrop L22/13 the fine lapilli are partly eroded and only exist in lenses that had a maximum original thickness of $10 \mathrm{~cm}$. Pumice clasts are microvesicular and contain moderate amount of crystals (5-10 vol\%) mainly px and pl. Regarding the major element composition, the rhyolithic MgT shows intermediate $\mathrm{SiO}_{2}$ and $\mathrm{K}_{2} \mathrm{O}$ contents $\left(\mathrm{SiO}_{2}=\right.$ $\left.71.2 \mathrm{wt} \% ; \mathrm{K}_{2} \mathrm{O}=2.9 \mathrm{wt} \%\right)$ but the highest $\mathrm{TiO}_{2}(0.47 \mathrm{wt} \%)$ concentrations of tephras with $>70 \mathrm{wt} \% \mathrm{SiO}_{2}$ (Figs. 7 and 8; supplementary data 3). It describes the least evolved composition in a trend that roughly spans from FeT, over LPT, to ST and lies on the endmember position of a differentiation line that encompasses the subsequent Tolapa Tephra. Trace element measurements of MgT are not available so far.

\subsubsection{Tolapa Tephra (ToT)}

Unit IX, the Tolapa Tephra, is the most widespread sequence of fall and flow units found in the Malpaisillo tephra sequence and the six subunits follow a $1.3 \mathrm{~m}$ thick developed paleosol (Figs. 2, 5, 6; supplementary Fig. 1; supplementary datas 1,2 ). The outcrops are distributed around the entire caldera and can be traced until $320 \mathrm{~km}$ to the south in the Pacific, offshore Costa Rica (Schindlbeck et al., 2016a; $2 \mathrm{~cm}$ thick G1). The stratigraphy of Unit IX differs partly between the northern and southern outcrops.

In the north, the tephra sequence starts with a thin, fine-grained, initial pumice fallout ( $8 \mathrm{~cm}$; fine lapilli; $\mathrm{L} 22 / 13$; Subunit IXa) that overlies a $20 \mathrm{~cm}$ thick, surge layer (Subunit IXb), and the two subsequent thick (up to $\sim 2.40 \mathrm{~m}$ and $\sim 0.8 \mathrm{~m}$; Subunits IXc and d) and coarse pumice fallout layers that have variable amounts of hydrothermal lithics (5 to 12 vol\%). At some outcrops (L51/13) only the surge deposits can be observed at the base. In contrast, two 1.6 to $2 \mathrm{~m}$ thick pumice fallout layers with a normal-graded top (Subunits IXc and d) and with predominant medium-sized lapilli and minor hydrothermally altered lithics (5-10 vol\%) directly overlie the paleosurface in the south.

In both regions an up to $20 \mathrm{~m}$ thick flow sequence terminates the tephra deposits of ToT. In the north (e.g. L22/13) occurs an initial, $\sim 30 \mathrm{~cm}$ thick, partly lithic-rich (rounded grey, "lithic-pumices" of previous units), poorly-sorted and massive fine to medium lapilli horizon that is overlain by a thin accretionary lapilli-bearing ash-rich horizon (L51/13; Subunit IXe). In contrast, the southern outcrops (e.g. L6/15) show laterally variable 50 to $400 \mathrm{~cm}$ thick surge deposits that are characterized by meter-scaled cross stratification and anti-dune structures containing also some minor amounts of accretionary lapilli (L6/15). This is followed by an up to $16 \mathrm{~m}$ thick, massive and poorly-sorted, matrix-supported ignimbrite (subunit IXf) containing several flow units and moderate amounts ( 10 to $30 \mathrm{vol} \%$ ) of fine to coarse, rounded, highly vesicular pumice lapilli and up to $15 \mathrm{vol} \%$ of fresh lithic fragments. The flow units are distinguished from each other by pumiceenriched horizons at the top and lithic concentrations at the base. In southern outcrops (L3/15) lapilli pipes, filled with lithic fragments cutting across the flow units, can be observed. At outcrop L6/15, located in an area of paleo-valleys and hills, the first several meters thick flow unit is made of a poorly-sorted and finest-depleted, clast-supported ignimbrite with $>50 \mathrm{vol} \%$ of sub-rounded to well-rounded, medium to coarse-grained, pumice lapilli and a moderate content (up to 15\%) of fresh mm- to partly cm-sized lithic fragments. Here, at least two flow units can be recognized due to changes in grain sizes that can be traced laterally along the entire outcrop.

Overall, the highly vesicular juvenile pumice clasts have uniform, large, elongated vesicles and contain minor amounts of phenocrysts ( $<5$ vol\%; pl $>$ px $>>$ qtz). ToT has a unique rhyolitic composition within the Malpaisillo tephra sequence (Fig. 7) and is characterized, except for PPT, by moderate $\mathrm{K}_{2} \mathrm{O}$ contents (2.97-3.18 wt\%) at lower $\mathrm{SiO}_{2}$ (71.4-72.8 wt\%) compared to the older tephras (Fig. 7). Moderate to high concentrations in ferromagnesian elements and $\mathrm{CaO}$ are accompanied by high $\mathrm{TiO}_{2}$ and $\mathrm{Al}_{2} \mathrm{O}_{3}$ contents (Fig. 8, supplementary data 3 ). Trace element concentrations in comparison to the other tephra units are moderate but still can be used to assist discrimination by major elements (Fig. 9).

\subsubsection{Lower (LMT), Middle (MMT), and Upper Maderas Negras (UMT) Tephras}

The Malpaisillo tephra sequence is completed by the Lower, Middle, and Upper Maderas Negras Tephras (Unit X to XII) that are only present in two outcrops (L29/13; L31/13) in the southeastern part of the Malpaisillo Caldera, where they follow the ToT after an incipient soil (Figs. 2, 5, 6; supplementary Fig. 1; supplementary datas 1,2). Whereas between the LMT and MMT no signs of a longer eruption break can be identified (e.g. paleosol, discordance) and only the chemistry suggest two different units, an incipient soil between MMT and UMT (L31/13) justifies the differentiation into Unit X to XII.

LMT (Unit X) consists of a thin $(\sim 25 \mathrm{~cm})$, basal inverse- and at the top normal graded fallout, consisting of fine to medium pumice lapilli, followed by a $\sim 20 \mathrm{~cm}$ thick surge layer showing lenses of rounded highly vesicular fine pumice lapilli in a cross stratified ash matrix. Subsequently, two $\sim 180 \mathrm{~cm}$ and $\sim 110 \mathrm{~cm}$ thick medium- to coarsegrained pumice lapilli layers and a thin $(\sim 65 \mathrm{~cm})$ ignimbrite deposit are identified in the outcrops (MMT; Unit XI). Fallout and ignimbrite deposits are lithic poor $(<5 \mathrm{vol} \%, \mathrm{~mm}$ - to $\mathrm{cm}$-sized hydrothermal altered and fresh lithics). The first thicker fallout is normal-graded within the uppermost $\sim 10 \mathrm{~cm}$. The mainly white but also silver and streaky pumice clasts have large subspherical and elongated vesicles, and contain up to $10 \mathrm{vol} \%$ of phenocrysts ( $\mathrm{pl}, \mathrm{px}$ and $\mathrm{ol}$ ).

UMT (Unit XII) is only observed in outcrop L31/13 and L29/13. It is represented by a thin fallout layer $(\sim 12 \mathrm{~cm}$; Subunit XIa), overlain by a $\sim 75 \mathrm{~cm}$ thick matrix-supported ignimbrite (Subunit XIIb) that contains fine-grained, highly vesicular, streaky white-greyish/silver pumice lapilli with microvesicles and some pl, px and qtz $(<5$ vol\%) as well as few $(<5$ vol\%) scattered mm-sized lithics.

Compositionally all Maderas Negras tephras belong to medium-K rhyolites. From LMT over MMT to UMT $\mathrm{SiO}_{2}$ and $\mathrm{K}_{2} \mathrm{O}$ increase successively and therefore the tephras can easily be distinguished from each other and from the other tephras by the total alkali concentrations (LMT: $\mathrm{SiO}_{2}=69.5 \mathrm{wt} \%, \mathrm{~K}_{2} \mathrm{O}=2.7 \mathrm{wt} \%$; $\mathrm{MMT} \mathrm{SiO}_{2}=70.7-71 \mathrm{wt} \%$, $\mathrm{K}_{2} \mathrm{O}=2.3-2.4$ wt\%; UMT: $\mathrm{SiO}_{2}=72.7-73.9 \mathrm{wt} \%, \mathrm{~K}_{2} \mathrm{O}=2.8-2.9 \mathrm{wt} \%$; Figs. 7, 8, supplementary data 3). Trace element concentrations between LMT and UMT are not as distinct but show the lowest Rb, La, Th and highest $\mathrm{Sr}$ concentrations, as well as the highest $\mathrm{Ba} / \mathrm{Rb}$ and lowest $\mathrm{Zr}$ / $\mathrm{Nb}$ ratios of all rhyolitic Malpaisillo/Monte Galán tephras, except for PPT (Fig. 9).

\subsection{Compositional distinction of the Malpaisillo and Monte Galán mag- matic systems}

Tephra products from the Malpaisillo and Monte Galán Calderas are in general compositionally similar to the well-studied HolocenePleistocene tephras of Nicaragua except for the high alkali $\left(\mathrm{K}_{2} \mathrm{O}=\right.$ 2.0-3.93 wt\%; $\mathrm{Na}_{2} \mathrm{O}=3.9-5.3$ wt\%; Fig. 10) and low $\mathrm{CaO}$ concentrations at given $\mathrm{SiO}_{2}$ content. Equally, the highest $\mathrm{Ba} / \mathrm{La}$ ratios of the entire CAVA are found in the Malpaisillo/Monte Galán tephras and are accompanied by higher $\mathrm{Rb} / \mathrm{La}$ and $\mathrm{Ba} / \mathrm{Nb}$ values compared to tephras from the modern Nicaraguan arc front. 

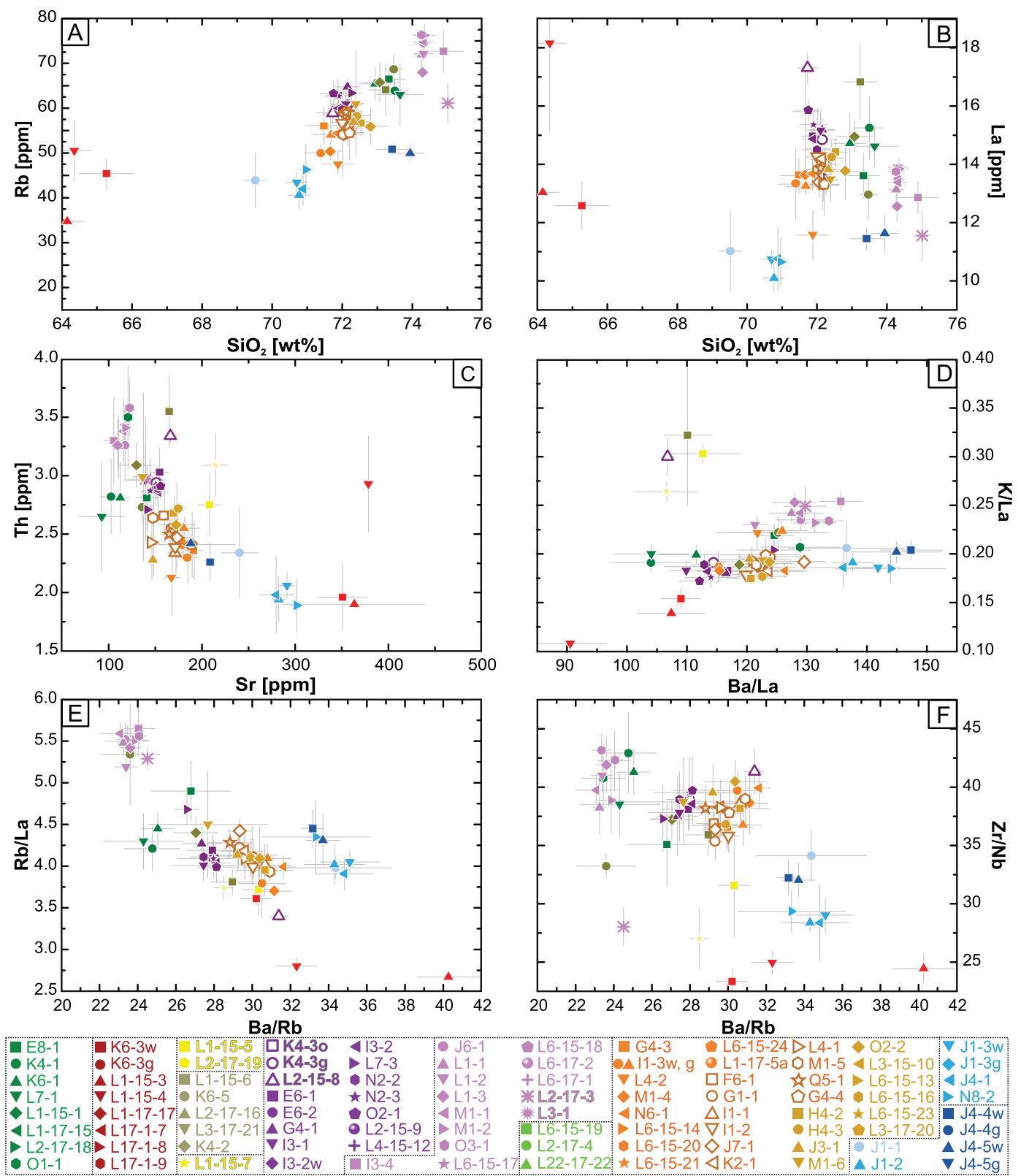

Fig. 9. Differentiation trends of Malpaisillo/Monte Galán tephra samples using trace element glass shard compositions. For color coding and explanation see Fig. 7. Compositional variations per analyzed tephra are shown with grey bars. Additional diagrams are given in supplementary Fig. 3.

Two parallel trends are visible in a diagram of FeOt versus MgO that compositionally distinguish the youngest tephras (X to XII, Figs. 7, 8, 9) and Unit VII by less FeOt at a given $\mathrm{MgO}$ value from other Malpaisillo/ Monte Galán tephras. The two trends are also visible in the $\mathrm{K}_{2} \mathrm{O}$, and $\mathrm{CaO}$ versus $\mathrm{SiO}_{2}$ diagrams (Fig. 8) but here the Sabanettas Tephra (Unit VII), as well as the less evolved Unit II, do not match the trends. Generally less evolved younger tephras perfectly match the discrimination fields given for the Holocene Nicaraguan tephras of the volcanic front (Fig. 10). These trends are not as obvious in trace elements, but nevertheless, may indicate a change in magma composition with time toward slightly less differentiated magmas due to larger mafic replenishments after each eruption, less time for differentiation of the products of the later eruptions and thus a higher eruption frequency, changes in the primary magma generation, or a combination of these factors (e.g. Chiltepe Volcanic Complex; Kutterolf et al., 2011; Freundt et al., 2006b). Major element variations like $\mathrm{CaO}$-enrichment in the magmas of the second trend may be explained by fractional crystallization with either a higher quantity of orthopyroxene in comparison with more clinopyroxene in trend
1 or a secondary enrichment linked with lower plagioclase fractionation. Alternatively, since $\mathrm{K}_{2} \mathrm{O}$, La and $\mathrm{Zr}$ concentrations are distinct at identical $\mathrm{SiO}_{2}$ (i.e., at the same extent of differentiation), the chemical variations of the source magmas may indicate different source volcanoes; e.g. Malpaisillo versus Monte Galán Caldera. Such a distinction between volcanic products from the two calderas has so far not been possible. The two different recurrent compositional trends, identified in the present study, may distinguish the origin of the eruptions from the two different calderas. Additionally, it is remarkable that the eruptions of the second, less evolved trend seem to be generally smaller in magnitude and that the outcrops are all concentrated next to the much smaller Monte Galán Caldera. We therefore propose that most tephras are associated with the Malpaisillo Caldera whereas the younger ones (LMT, MMT, UMT) and probably also the Punta de Plancha Tephra may be sourced from the Monte Galán Caldera (Figs. 10 and 11). However, a confirmation of this hypothesis has to wait on more proximal stratigraphic constraints from the Monte Galán Caldera and detailed petrogenetic work involving additionally bulk rock data. 

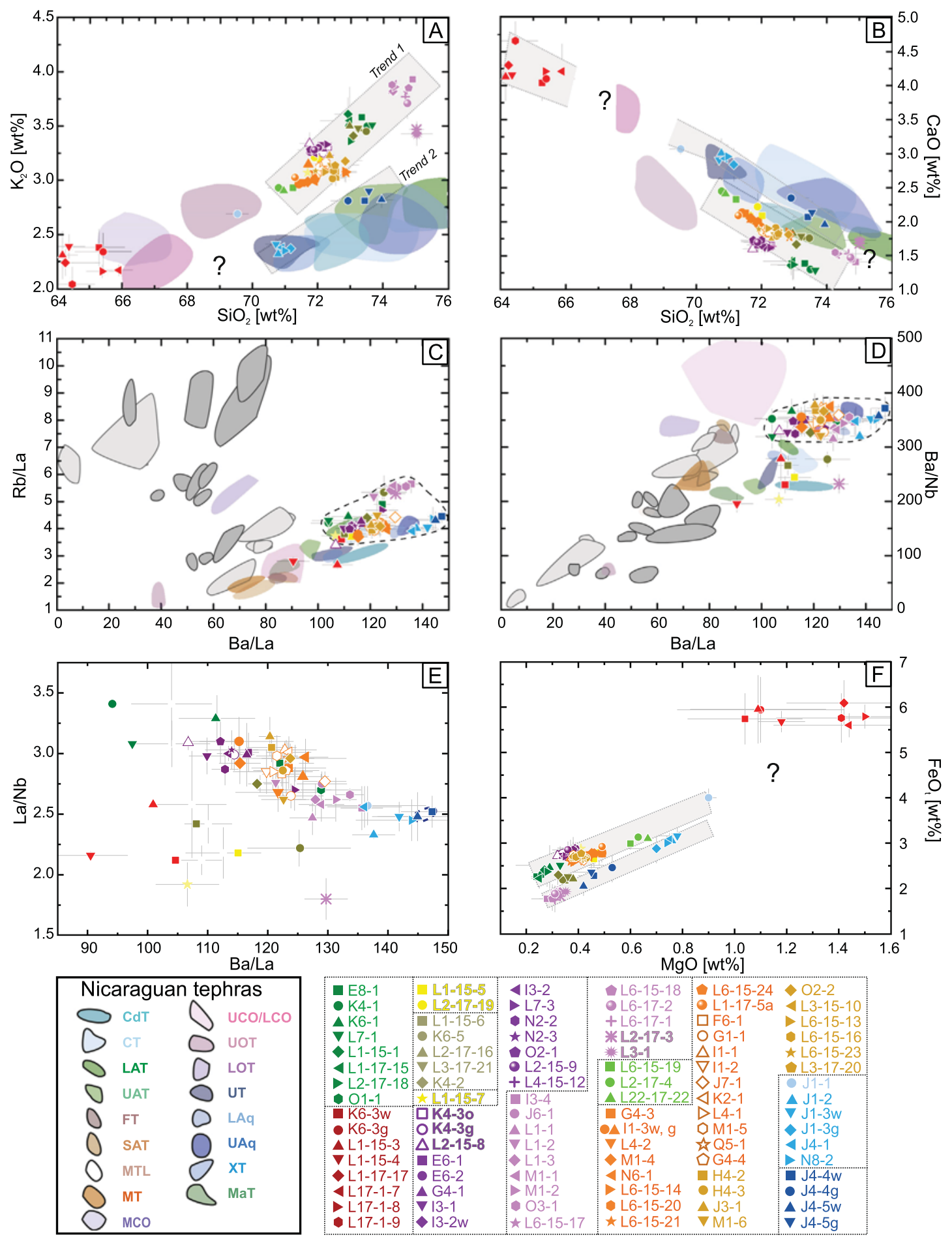

Fig. 10. Differentiation diagrams of Malpaisillo/Monte Galán tephra samples using major and trace element glass shard compositions and their ratios compared with major element glass composition fields of Late Pleistocene Nicaraguan tephras and trace element glass compositional fields of the entire CAVA after Kutterolf et al. (2007, 2008a). Light grey fields in C, D represent tephras from El Salvador and dark grey fields tephras from Guatemala. The relevant tephra acronyms represent the following Nicaraguan tephras units: UCO/LCO = Upper/Lower Cosigüina Tephra, UOT = Upper Ometepe Tephra, LOT = Lower Ometepe Tephra, UT = Unicit Tephra, LAq = Lower Apoyeque Tephra, UAq = Upper Apoyeque Tephra, XT = Xiloa Tephra, MaT = Mateare Tephra, CdT = Los Cedros Tephra, CT = Chiltepe Tephra, LAT = Lower Apoyo Tephra, UAT = Upper Apoyo Tephra, FT = Fontana Tephra, SAT = San Antonio Tephra, MTL = Masaya Triple Layer, MT = Masaya Tuff, MCO = Mafic Cosigüina Tephra. Two compositional trends can be discriminated for the Malpaisillo Formation in A, B.

\subsection{Eruptive volumes, masses, and distribution}

\subsubsection{Areal distribution}

Proximal outcrops were found around the entire Malpaisillo and Monte Galán calderas, except to the west-southwest where they are covered by younger sediments. Most of the medial outcrops studied are located south and southeast and can be found up to $230 \mathrm{~km}$ south of the Malpaisillo Caldera along the road heading to La Paz Centro and in the town itself as well as in direction to Nagarote (Figs. 2, 11, 12). Distal ash outcrops were found as far as $350 \mathrm{~km}$ offshore Costa Rica and 530 km offshore Guatemala in the Pacific (Schindlbeck et al., 2016a, b, submitted). 

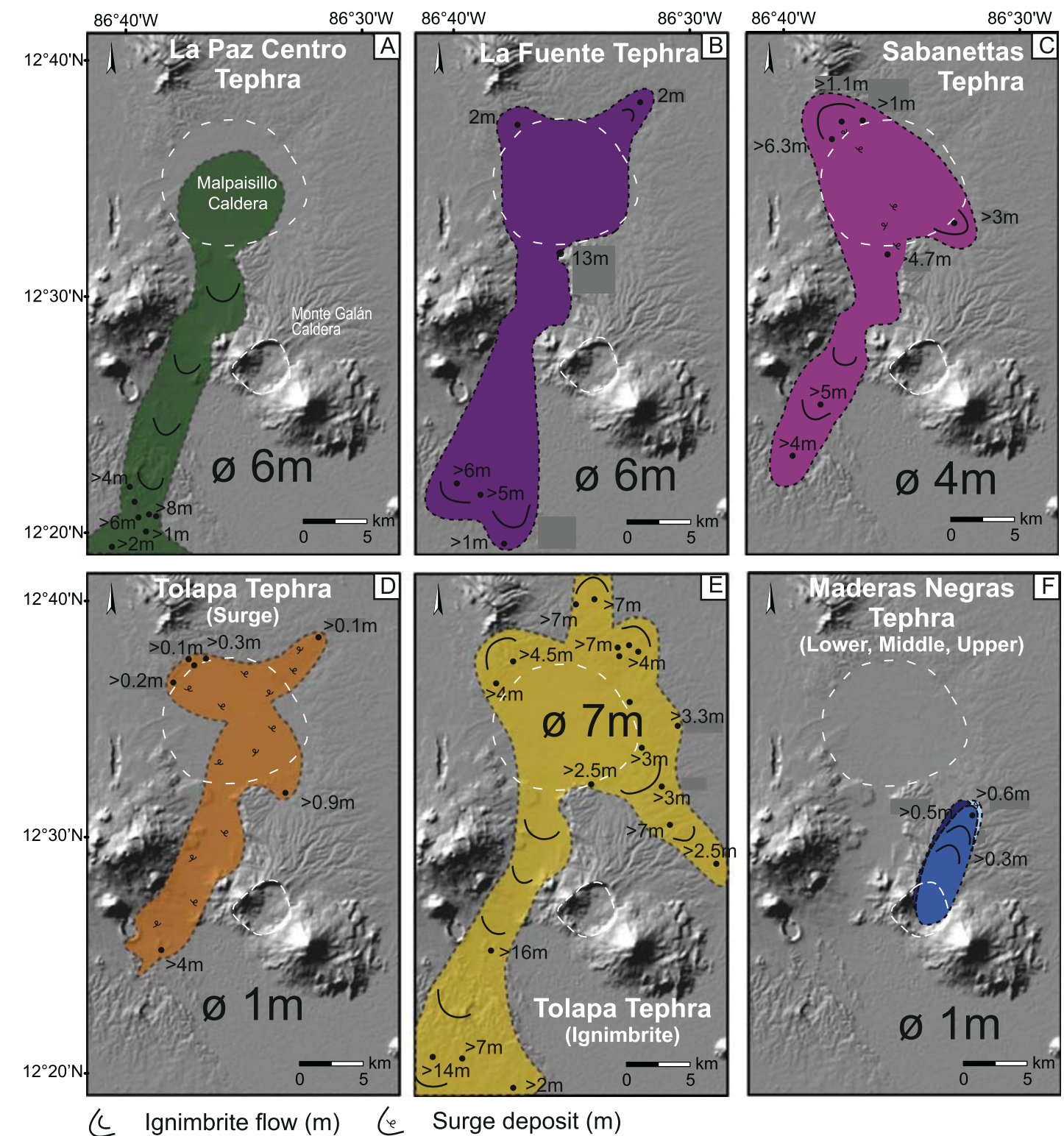

(c) Ignimbrite flow $(\mathrm{m})$ (e Surge deposit $(\mathrm{m})$

Fig. 11. Digital elevation models (DEM) showing the areal distribution of pyroclastic flows and surge deposits in the area of the Malpaisillo/Monte Galán Calderas. The deposits belonging to different geochemical groups/tephras are presented in separated maps. In case of successive flow units, their respective thicknesses are summarized. Minimum thicknesses (>\#) are given for incomplete exposure of a given unit. Average thicknesses, used for volume determination, are given for each unit. Surge deposits have generally small distribution and therefore are incorporated in the general map of the pyroclastic flows. Only Tolapa Tephra (D) surge deposits have a sufficient wide distribution to be shown here.

\subsubsection{Pyroclastic density currents}

Ground transport and the extension of flow deposits are controlled by paleomorphology. Therefore, the observed flow deposits (surges and ignimbrites) from the older eruptions all follow a south/southeastern distribution where paleo-valleys apparently favored the longdistance travelling of the flows and reached at least $23 \mathrm{~km}$ to the southwest and $11 \mathrm{~km}$ to the southeast from the Malpaisillo Caldera rim, covering a minimum area of $390 \mathrm{~km}^{2}$ (Fig. 11). Flow deposits from the younger (LMT, MMT and UMT) eruptions are limited to the southeast of the Malpaisillo Caldera and the north of the Monte Galán Caldera supporting their proposed origin from the latter. Since ignimbrite deposits are rarely exposed from base to top the metrics of the deposits given here are all minimum cumulative values estimated from the distribution areas and corresponding thicknesses at different distances from the calderas (supplementary data 5). The LMT, MMT and UMT, include only minor voluminous flow deposits that are estimated to have distribution areas of $\sim 30 \mathrm{~km}^{2}$ with thicknesses of $100 \mathrm{~cm}, 9 \mathrm{~km}$ from the vent, corresponding to tephra volumes of $0.03 \mathrm{~km}^{3}$, each. In contrast, ignimbrite and surge deposits of LPT, FeT and ST are much more widely distributed (180 to $250 \mathrm{~km}^{2}$; Fig. 11 ; supplementary data 5), have larger thicknesses ( 400 to $600 \mathrm{~cm} ; 25$ to $32 \mathrm{~km}$ from vent) that are evenly distributed between the multiple flow units, and consequently have higher erupted tephra volumes (LPT $=0.8 \mathrm{~km}^{3} ; \mathrm{FeT}=$ $1.5 \mathrm{~km}^{3} ; \mathrm{ST}=1.0 \mathrm{~km}^{3}$; supplementary data 5).

By far the largest erupted flow volumes can be attributed to the Tolapa Tephra. Initial surges (subunit IXa) emplaced thin tephra sheets only locally exposed in the north of the caldera. Surge deposits from subunit IXe, are much wider distributed but difficult to estimate due to the large thickness variations. Rough estimates give a tephra volume of $0.16 \mathrm{~km}^{3}$, a distribution area of $160 \mathrm{~km}^{2}$, and thicknesses between 20 and $400 \mathrm{~cm}$. In contrast, the flow deposits in the upper part of ToT (subunit IXf) were so voluminous that they were not significantly controlled by topography and covered the entire area with a thick sheet of ignimbrite $\left(390 \mathrm{~km}^{2} ; 2.5\right.$ to $>16 \mathrm{~m}$ ), consisting of at least three flow units of 


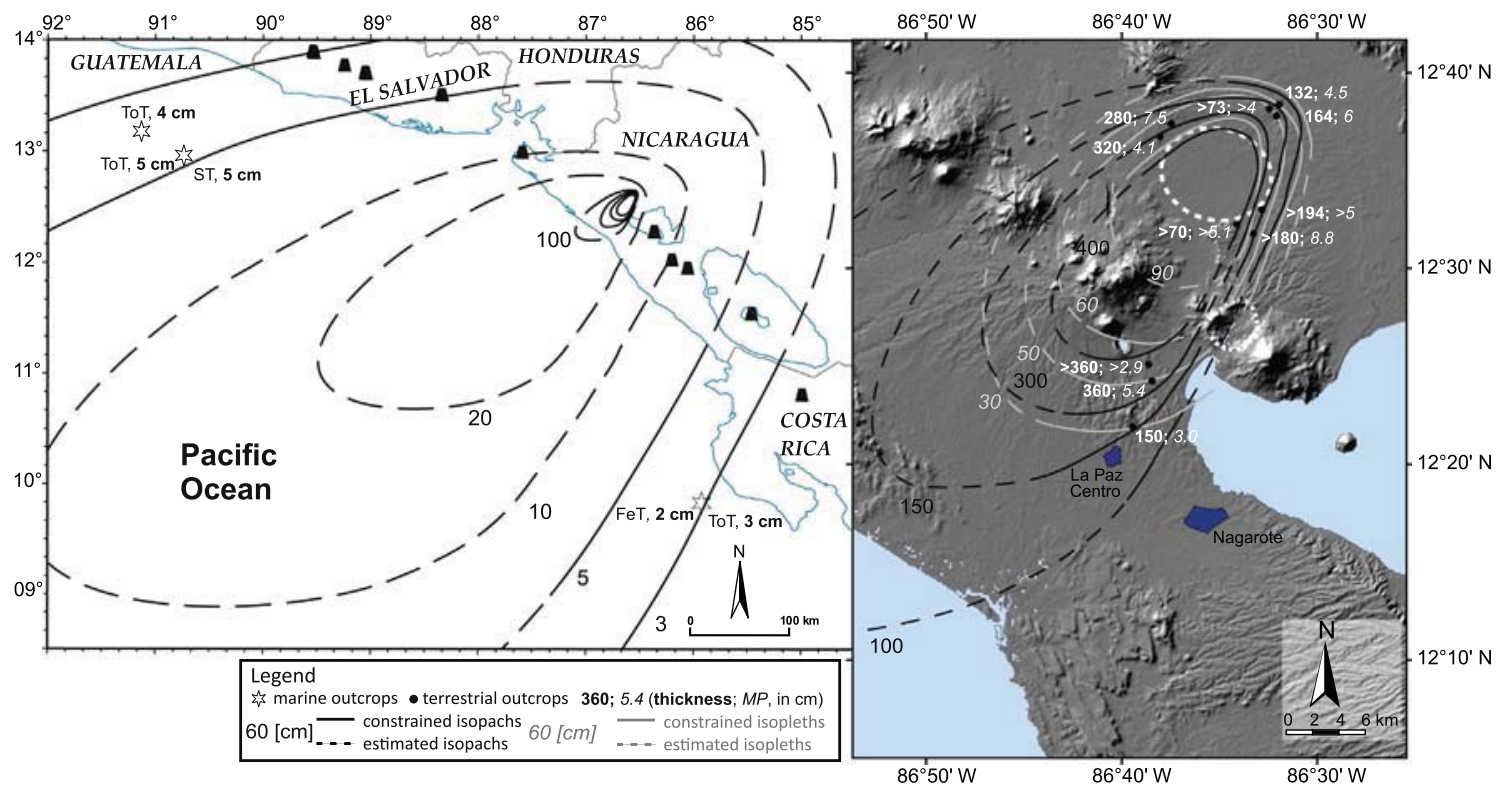

Fig. 12. Location map of the area north of Managua including the area around La Paz Centro, the Malpaisillo and Monte Galán Caldera and parts of the northern Nicaraguan active volcanic front as well as a schematic outline showing the Pacific coastal area of Northern Costa Rica, western Nicaragua and El Salvador. Proximal and distal isopachs as well as proximal isopleths from the Tolapa fallouts are shown. The two fall layers are summarized here as one layer. Distal thickness values in the Pacific are from Schindlbeck et al. (2016a, b, submitted). Solid lines are well-constrained, dashed lines are estimated. Isopach thickness (black) is given in cm; Isopleths (grey) are from maximum pumice clast sizes in mm. Black dots and stars show outcrop locations. Numbers next to outcrops indicates MP values, labeled with smaller italic numbers, and thickness data (bold numbers).

roughly equal volume, having a cumulated tephra volume of $2.7 \mathrm{~km}^{3}$ (supplementary data 5).

\subsubsection{Fallout}

Fallout deposits predominate in five Malpasillo eruptions (PPT, LCbT, GT, UCbT, MgT) but are observed in only few outcrops, limiting wellconstrained isopach and isopleth maps. Nevertheless, their distribution and grain size decays, taking into account their most likely eruptive centers, still allow for a very rough estimation of their eruptive volumes and eruption column heights. The resulting eruptive volumes range from $0.24 \mathrm{~km}^{3}$ (LCbT) to $2.3 \mathrm{~km}^{3}$ (MgT) with an areal coverage of $\sim 500 \mathrm{~km}^{2}$ (LCbT) to $2000 \mathrm{~km}^{2}$ (MgT) (supplementary data 5, Fig. 12) and thus provide a first estimate on eruption sizes. For FeT Schindlbeck et al. (2016a) also found a corresponding ash layer in the Pacific offshore Nicoya Peninsula, Costa Rica. A distance of $350 \mathrm{~km}$ to its source require a transport by air, enabled by a co-ignimbrite ash plume or the subunit Vla fallout. Consequently, the distal deposited ash volume of $\sim 2.7 \mathrm{~km}^{3}$ (Schindlbeck et al., 2016b) must be added to the volume estimates for the proximal and medial flow deposits summing up to $4.2 \mathrm{~km}^{3}$ tephra volume for the entire FeT. Sabanettas Tephra was also identified as $5 \mathrm{~cm}$ thick ash layer in marine deposits offshore Guatemala (Schindlbeck et al., submitted) and together with the $4 \mathrm{~m}$ proximal deposit accumulates to a roughly estimated total tephra volume of $\sim 14 \mathrm{~km}^{3}$, associated to a distribution of $\sim 0.5$ million $\mathrm{km}^{2}$. The potential Monte Galán Caldera eruptions also produced small fall deposits that accumulate to $1.8 \mathrm{~km}^{3}$ for PPT, $0.28 \mathrm{~km}^{3}$ for MMT, and $0.03 \mathrm{~km}^{3}$ for UMT, covering an area of several hundreds of square kilometers.

A sufficient outcrop density is only available for the Tolapa Tephra, thus allowing for well-constrained isopachs and isopleths. Here the two pumice layers were treated together as one fallout unit (IX c/d). Thickness measurements of 12 proximal to medial outcrops were used for the construction of isopachs (Fig. 12). They are complemented by three distal occurrences in marine drill cores offshore Costa Rica and Guatemala that have been correlated to ToT by Schindlbeck et al. (2016a, submitted; Fig. 12). If we treat the two fallout layers separately, the volume ratios between the lower and upper fall deposits would be $\sim 1.5: 1(\mathrm{~L} 6 / 15)$.
Downwind, toward the south and southeast, thicknesses decrease being constant over long medial distances, consistent with the prevailing wind direction in the lower stratosphere (e.g. Kutterolf et al., 2007). Including distal marine locations offshore northern Costa Rica extends the distribution to $320 \mathrm{~km}$ in the south and $530 \mathrm{~km}$ in the west. Erupted tephra volumes calculated for the ToT fallout unit yield $6.6 \mathrm{~km}^{3}$ for the proximal and medial portion and $117 \mathrm{~km}^{3}$ for the distal portion, summing up to $126 \mathrm{~km}^{3}$ including the volumes of the pyroclastic flows. This converts to $83 \mathrm{~km}^{3}$ DRE and therefore represents probably one of the largest eruptions in the Quaternary Nicaraguan arc systems (Fig. 13).

Outcrop densities for most individual fall units are not high enough to use isopleths of the maximum pumice clasts to infer eruption column heights (e.g. Carey and Sparks, 1986). Only the plinian eruption phase of Tolapa Tephra facilitates the use of systematic grain size decay with distance and comparison of maximum cross- and downwind range with the numeric models of eruption column heights after Carey and Sparks (1986). This gives an estimation of maximum eruption column heights of 28 to $34 \mathrm{~km}$ at a wind speed of 7 to $12 \mathrm{~m} / \mathrm{s}$ for ToT (Fig. 13).

\section{The Malpaisillo and Monte Galán Calderas and their volcanic haz- ards and risks}

\subsection{Eruptive history}

The lithostratigraphic succession, represented by the major stratigraphic units described above, is divided into at least 12 large-volume eruptive phases (Figs. 6, 14). They are separated by time breaks (unconformities, paleosols) sufficiently long (e.g. several thousands of years) to enable the emplacement of new, primitive magma batches and their evolution to rhyolitic composition (e.g. Reid, 2003).

Based on the actual state of knowledge and existing outcrops, the eruptive sequence of the Malpaisillo/Monte Galán calderas was initiated by the large explosive La Paz Centro eruption (LPT) that emplaced an ignimbrite unit with two flow units, only exposed in deeply incised paleo-valleys. Due to limited outcrop coverage, it is not clear if an eruption column was established or the associated pyroclastic flow was generated by "boiling over", nor if there have been eruptions before or if 

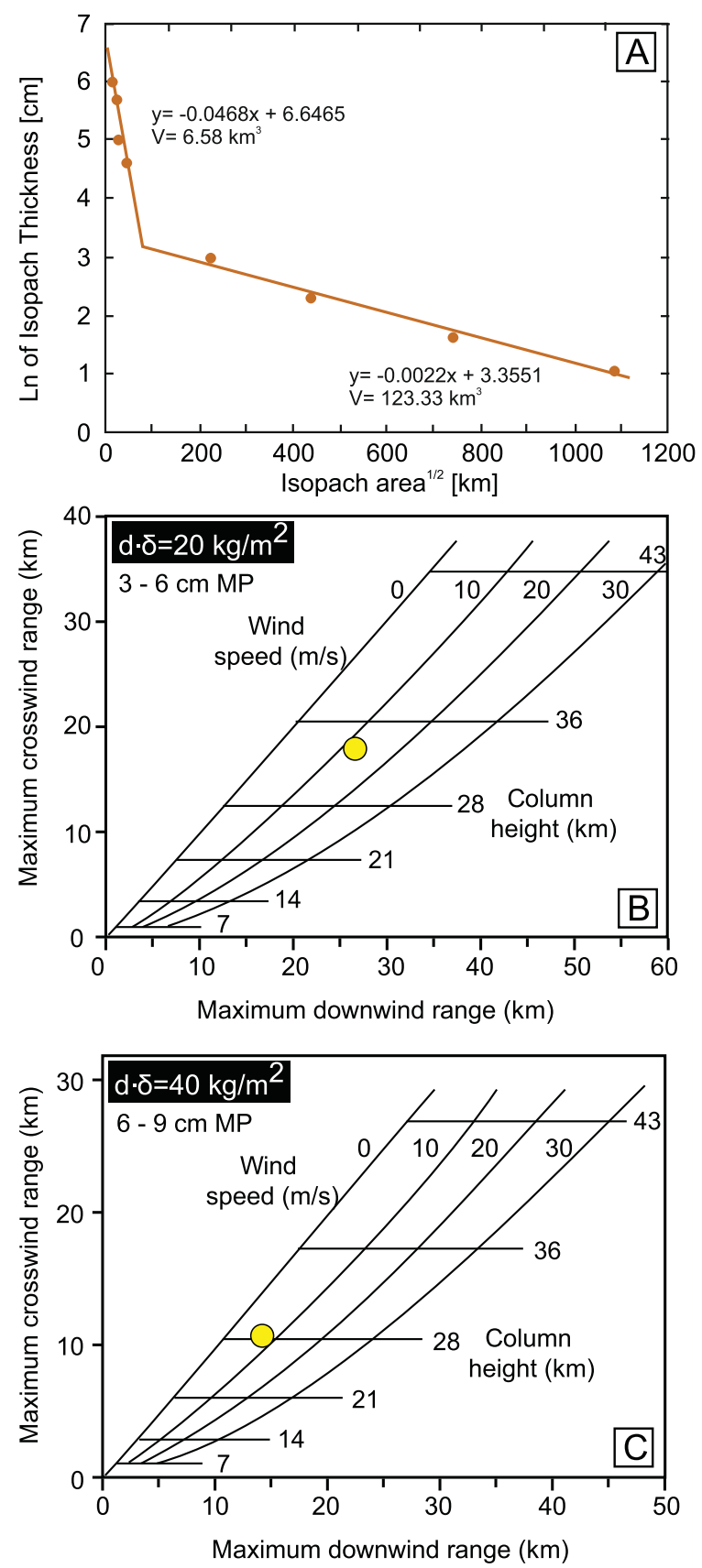

Fig. 13. A) Ln (isopach thickness) versus square-root (isopach area) diagram for Tolapa fallout. Linear regressions as indicated were used to calculate tephra volumes after Fierstein and Nathenson (1992). B - C) Diagrams of crosswind range versus downwind range for Tolapa MP isopleth data compared to model results of Carey and Sparks (1986). Clasts were selected to be close to, but are not identical to, the diameter $\times$ density products shown. The range of pumice sizes is given in diagrams and we used a density of $500 \mathrm{~kg} / \mathrm{m}^{3}$ for the pumice clasts referring to average measurements after Kutterolf et al. (2007). Horizontal grid lines indicate eruption column heights (in km) and diagonal grid lines show wind velocities (in $\mathrm{m} / \mathrm{s}$ ).

there has been an ancestor of a volcanic edifice or caldera structure (Fig. 14A). This first eruptive phase produced $1.1 \mathrm{~km}^{3}$ of tephra and was dated to $570 \pm 70 \mathrm{ka}$ by ${ }^{39} \mathrm{Ar}-{ }^{40} \mathrm{Ar}$ technique (supplementary Fig. 2). This $M_{v}=5.1$ eruption (Magnitude $M_{v}$ after Pyle, 2000) most probably originated from the Malpaisillo Caldera and likely caused the first caldera subsidence. After this initial eruption, the eruptive activity paused for hundreds to thousands of years, during which a thick paleosol and/or an erosional unconformity developed on top of the ignimbrite. The following volcanic activity in the region comprises four, moderately large $\left(\mathrm{M}_{\mathrm{v}}=4.5\right.$ to 5.5$)$, predominantly fallout producing eruptive events that emplaced first the Punta de Plancha Tephra (1.8 $\mathrm{km}^{3}$ tephra volume) that may be associated, on the base of its chemical signature, to a first volcanic event from Monte Galán Caldera. Oscillating eruption columns first emplaced stratified and multiply bedded Subunit Ila (surges and falls) before the eruption column got more and more stable and deposited the massive fallout subunits IIb, and IIc (Fig. 14B). Subsequently, the eruptions of Lower Chibola Tephra $\left(0.24 \mathrm{~km}^{3}\right)$, Guacucal Tephra $\left(2.3 \mathrm{~km}^{3}\right)$, Upper Chibola Tephra $\left(1.3 \mathrm{~km}^{3}\right)$, emplaced three individual fallout layers from stable eruption columns (Units III to V; Fig. 14C) that are geochemically associated to the Malpaisillo Caldera. During the La Fuente eruption (4.2 km³ , Unit VI; $480 \mathrm{ka}$ ), an initial thick and massive fallout is deposited from a stable eruption column of Malpaisillo Caldera that is followed by three massive ignimbrite flow units, associated with collapsing eruption columns and a caldera subsidence (Fig. 14D). Large lag breccia's observed at the base of the ignimbrites in outcrop L13/13, close to the Malpaisillo Caldera rim, contain high amounts of angular lithic fragments. Obsidian clasts with similar compositions like the juvenile pumice clasts indicate the presence of obsidian domes at the beginning of the eruption. Numerous hydrothermally altered lithics in the lowermost ignimbrite flow unit, along with fresh ones in the following units, can be interpreted to represent an older volcanic edifice, hydrothermally altered, and abraded first during the eruption before widening of the vent and/or subsidence of the caldera roof facilitated withdraw of fresher lithic material.

Sabanettas Tephra (Unit VII) deviates partly in its compositional trend from the Malpaisillo trend and may be associated with a Monte Galán origin (Fig. 10); however, without further stratigraphical and geochemical studies it is assigned here to Malpaisillo. Nevertheless its occurrence in the marine sediments offshore Guatemala suggests that it is amongst the most voluminous eruptive products originating from the Malpaisillo and Monte Galán Caldera systems $\left(15.1 \mathrm{~km}^{3} ; \mathrm{M}_{\mathrm{v}}=\right.$ 6.3), probably also associated with a caldera-forming event. Its age of $\sim 450 \mathrm{ka}$ is constrained by a correlation to marine tephras offshore $\mathrm{El}$ Salvador/Guatemala (Schindlbeck et al., submitted). The succession starts with deposits from surges (Fig. 14E) that contain a variable amount of accretionary lapilli. Subsequently, a thick fallout layer with several vaguely normal-graded beds without distinct contacts was deposited, followed by a succession of distinct thin fallout units. The multiple normal-graded fallouts represent either an unstable eruption column that fluctuates in intensity producing several interrupted fallouts or variable wind conditions, which displaces the axis of the distribution fan temporarily leading to decreasing grain sizes at given site away from the vent (e.g. Wilson and Houghton, 2000). Nevertheless, an increasing frequency of ash beds coming along with a thinning-up $(\sim 400 \mathrm{~cm}, 12 \mathrm{~cm}, 7 \mathrm{~cm}, 5 \mathrm{~cm}, 7 \mathrm{~cm}$, respectively) suggests increasing instability of the eruptive column ending with a final two-stage column collapse evidenced in a pair of pyroclastic flow deposits ( 3 in Fig. 14E) and an accretionary lapilli-bearing co-ignimbrite ash on top. The following medium-sized Miralago Tephra (Unit VIII; $0.9 \mathrm{~km}^{3} ; \mathrm{M}_{\mathrm{v}}=5.1$ ) represents a widespread, vaguely stratified pumice fallout that was emplaced from an oscillating, but stable, eruption column (Fig. 14F). Subsequently, the $420 \pm 40$ ka old Tolapa Tephra (Unit IX; ${ }^{39} \mathrm{Ar} /{ }^{40} \mathrm{Ar}$ dating see supplementary Fig. 2) is emplaced. A basal thin fallout deposit contains a thin lithic-rich horizon of hydrothermally altered fragments and was partially eroded by a subsequent basal surge. Surge deposits contain accretionary lapilli and therefore argue for interaction of the rising magma with groundwater or an existing crater lake. After the initial pulse of the eruption when the conduit was cleaned and the vent widened, a stable eruption column ( 28 to $34 \mathrm{~km}$ ) was established that emplaced two widespread $\left(1.2 \times 10^{6} \mathrm{~km}^{2}\right)$ pulses of voluminous fallouts ( $123 \mathrm{~km}^{3}$ fallout), reflecting the largest part (of the high magnitude eruption ( $126 \mathrm{~km}^{3} ; \mathrm{M}_{\mathrm{v}}=7.2 ;$ Fig. $14 \mathrm{G}$ ). Subsequently, the mass discharge rate became probably too large to sustain a stable eruption column and lead to a first eruption column collapse and subsequent surges. Progressive emptying of the magma chamber finally caused subsidence of the magma chamber roof and emplacement of thick ignimbrite flow units in the lower topography toward the south 


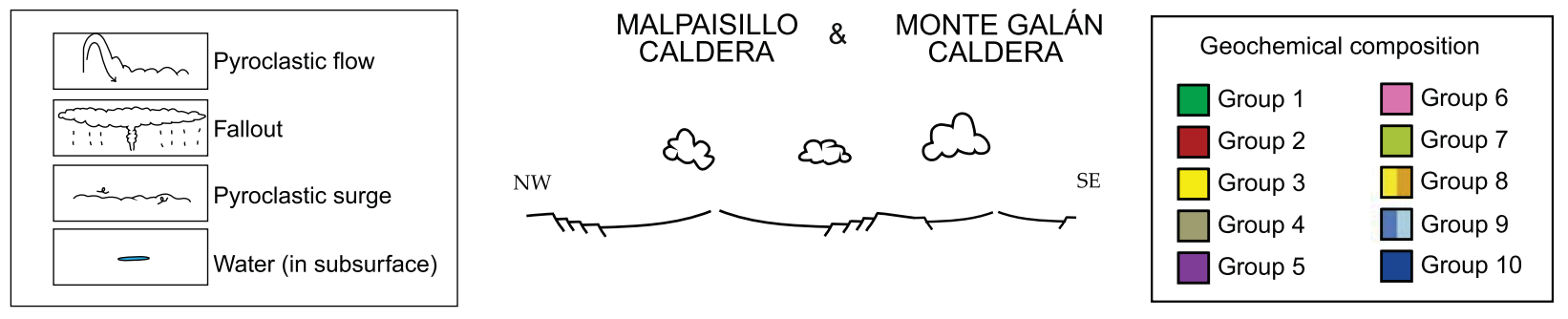

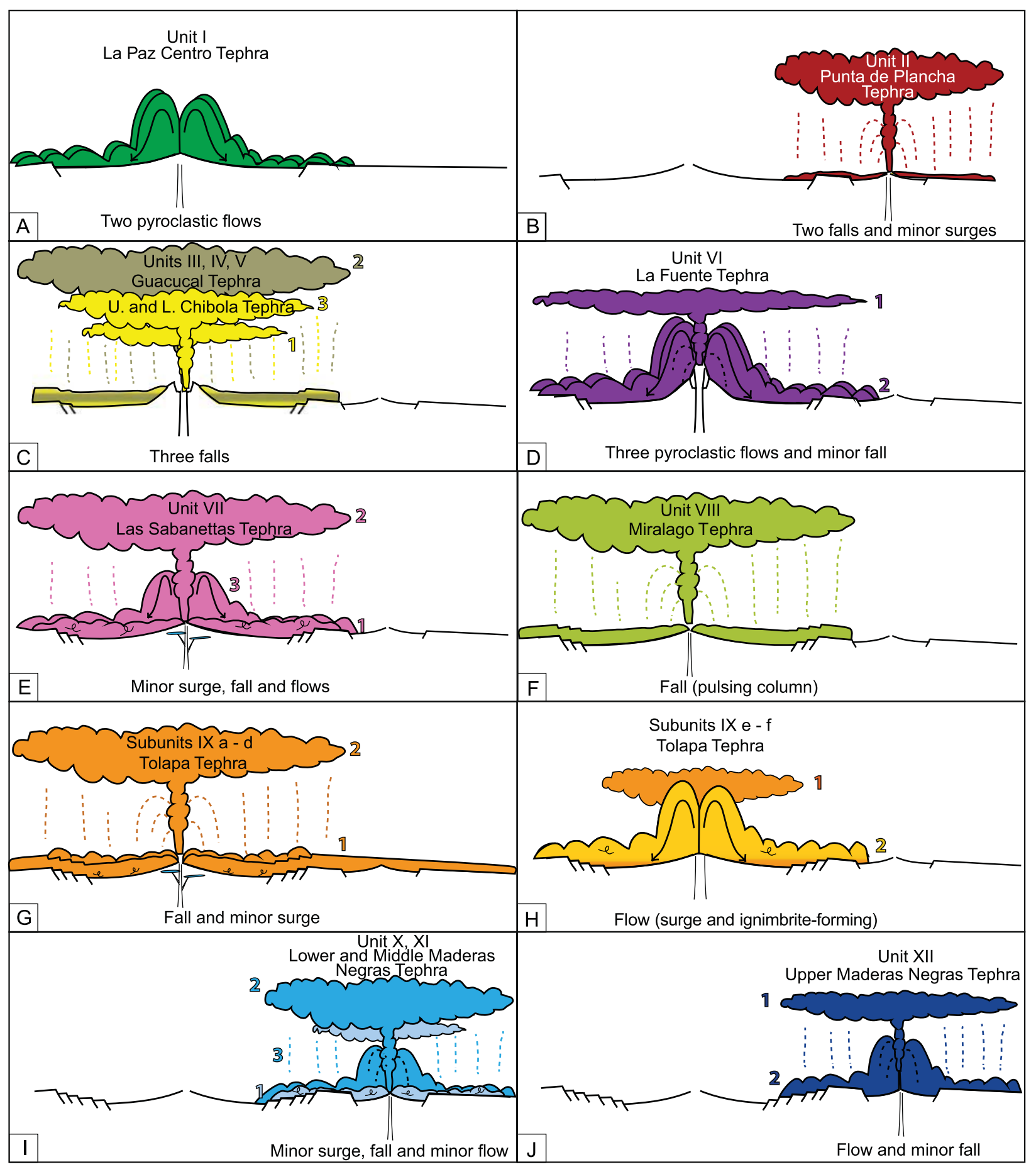

Fig. 14. Schematic eruptive history of the Malpaisillo and Monte Galán calderas indicating inferred caldera collapses that occurred after some eruptive phases (number of listric faults at the caldera rim) and dominant emplacement processes for each respective stratigraphic unit. The color code refers to the geochemical groups defined in Fig. 7. For Tolapa Tephra the subphases are given in two diagrams. Note: eruption column heights are estimated and shown relative between the individual tephra units to reflect changes in thicknesses and grains sizes between them at similar distances to the vent, respectively. 
(Fig. 14H). This is especially evident in the ToT stratigraphy of outcrop L6/15 where large normal faults, pointing toward the center of the caldera ring structure, affected the entire older tephrostratigraphy but not the uppermost part of ToT within the thick ignimbrite sheet.

Lower, Middle and Upper Maderas Negras Tephras represent the youngest tephra deposits in the region. They can clearly be attributed to a different magmatic series, which is most probably associated with the Monte Galán Caldera since the deposits are all concentrated at the southeastern rim of the Malpaisillo Caldera close to the Monte Galán Caldera. Future stratigraphic and geochemical studies are needed to confirm this. The tephra units (Units X to XII) originated from these last eruptive events are smaller $\left(0.03 \mathrm{~km}^{3}\right.$ to $0.3 \mathrm{~km}^{3} ; \mathrm{M}_{\mathrm{v}}=3.7$ to 4.6), often emplaced after an initial surge event by a stable eruption column that collapsed finally, and produced a sequence of fallouts followed by flow deposits (Fig. 14I, J).

\subsection{Volcanic hazards and risks}

Many active explosive volcanoes may threaten western Nicaragua by various types of volcanic hazards. The vulnerability of the population, living mainly in the vicinity of the active volcanic arc, is considered to be high in western towns and extremely high in the area of the capital Managua but also in the highly populated region between León and Nagarote. Although the last activity of the Malpaisillo and Monte Galán Calderas has taken place hundreds of thousands of years ago we cannot exclude future eruptions since large volcanic systems have larger recurrence times than the usual arc volcanoes (e.g. Mason et al., 2004; Brown et al., 2014). We cannot predict if and when a future eruption may occur but we can evaluate what past eruptions have caused in the respective vulnerable region of Nicaragua. Pyroclastic flows with their enormous destructive power and sudden unpredictable occurrence represent the major hazard of a future Malpaisillo-type eruption at proximal and medial distances since they would cover the entire area up to $\sim 30 \mathrm{~km}$ distance from the caldera, including the town of La Paz Centro, with meter thick ignimbrites (Fig. 15). Fallouts are the second important threat for the population and affect also the areas at larger distances. With respect to average Nicaraguan roof quality, fallout thicknesses of $\sim 10 \mathrm{~cm}$, or even less for compacted wet tephra, are probably often sufficient in the wider area of Malpaisillo, including the capital Managua, to cause roof collapse in response to rapid accumulation (e.g. Freundt et al., 2006b), as suggested for instance by the distribution of the fallouts of the Tolapa Tephra (Fig. 15).

\section{Conclusions}

Here we present a tephrostratigraphy for eruptive products emitted by the Malpaisillo and Monte Galán Calderas and refine the mid to late Pleistocene Malpaisillo Formation proposed by Kutterolf et al. (2007). We have mapped, characterized, quantified, and partly dated twelve tephra units and assign their origin to either the Malpaisillo or the Monte Galán Calderas on the basis of the geochemical signatures. Our findings provide a better understanding of the eruptive behavior and evolution of Nicaraguan volcanoes since the Pleistocene, especially in the so far less well-constrained northern part of the Nicaraguan arc. Major results are:

- Stratigraphy and major and trace element compositions define twelve tephra units representing different eruptive phases separated by palesols, clear unconformities, or distinct changes in compositions.

- Based on compositional differences and the areal distribution LPT, LCbT, GT, UCbT, FeT, MgT, and ToT likely originated from the Malpaisillo caldera, whereas the UMT, MMT, LMT, most probably the PPT and eventually the ST may have been derived from the Monte Galán Caldera.

- Emplacement of the larger tephra units LPT, FeT, ST, and ToT each potentially led to subsidences that formed the final multi-stage caldera structure.

- The medium- to high-K rhyolitic Malpaisillo tephras are characterized by higher alkali contents as well as higher $\mathrm{Ba} / \mathrm{La}$ ratios compared to other Nicaraguan volcanic deposits, whereas the younger dacitic to rhyolithic Monte Galán tephras more closely follow the trends of the modern arc.

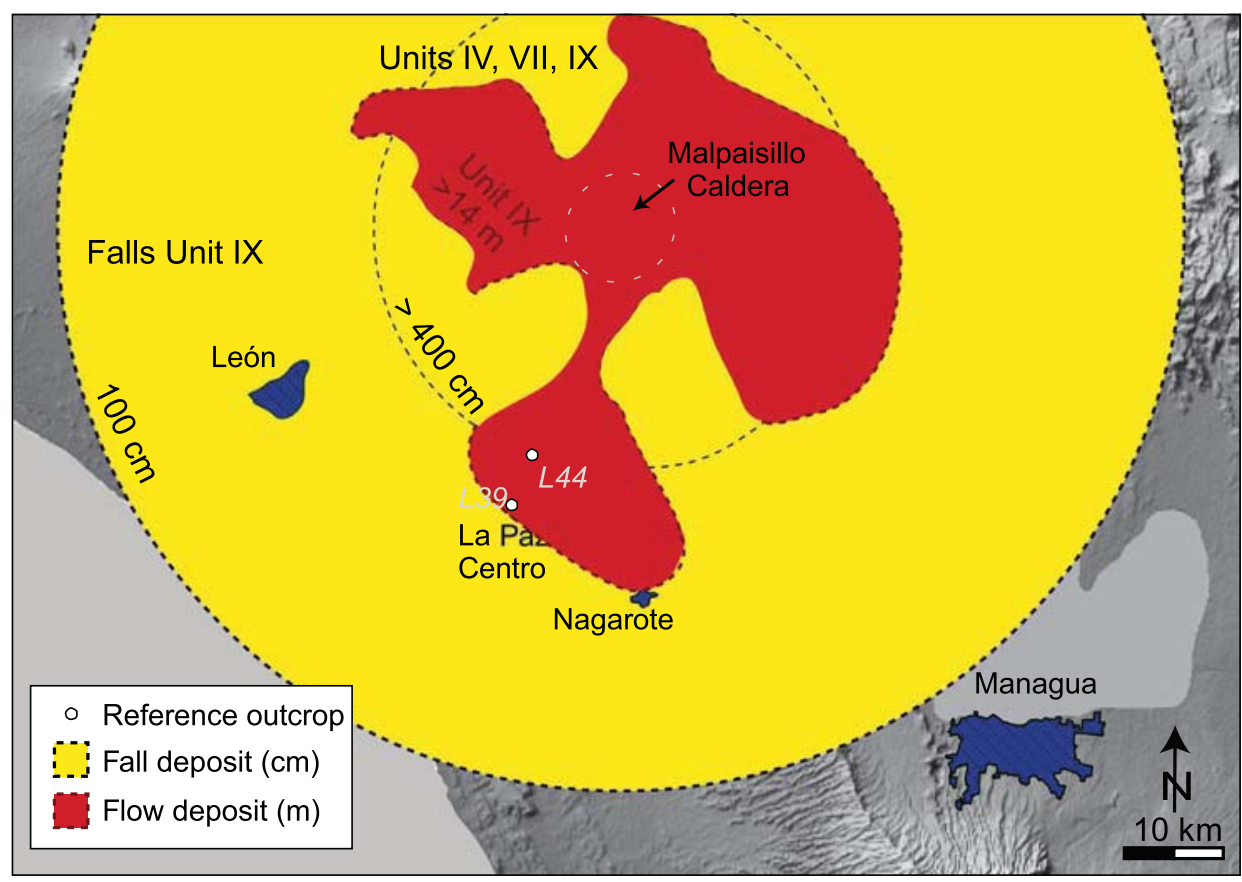

Fig. 15. Hazard map for a possible future Malpaisillo-type eruption based on the thickest deposits observed in the field. The eruptive phase, on which each projection is based, is indicated. (1) The $14 \mathrm{~m}$-isoline of ignimbrite thickness distribution as established in outcrop L39 (Unit IX), is an estimation projected on the actual topography. Pyroclastic density flows of Units I, VI and VII have similar minimum distributions but smaller and not as well-constrained thicknesses. (2) The $100 \mathrm{~cm}$-fallout isopach is a projection based on the isopachs reconstructed for the falls of Unit IX (Tolapa Tephra) (3) The $400 \mathrm{~cm}$-fallout isopach, based on the outcrops L44/13 (Unit VII), L6/15 (Unit IX), L1/15 (Unit IV?) and represents minimum thicknesses. The prediction of fallout thicknesses is based on an eruptive center in the middle of the caldera, without considering the wind direction for dispersion pattern. 
- The new radiometric ages, between 420 (ToT) and $570 \mathrm{ka}$ (LPT), are much older than the other Quaternary volcanic deposits in Nicaragua and are complemented by age estimates derived from marine sedimentation rates (FeT, $480 \mathrm{ka}$; ST, $\sim 450 \mathrm{ka}$ ). They contribute to fill the gap in the Nicaraguan volcanic history between the Tertiary Coyol Group and the deposits from the modern arc (e.g. Schindlbeck et al., 2016b).

- Highly explosive, plinian activity led to deposition of thick flowrelated tephras through boiling over (LPT, FeT, Upper ToT), volcanic plume and collapse of the latter (ST, ToT, LMT, MMT, and UMT) as well as fallouts from stable or fluctuating eruption columns (PPT, LCbT, GT, UCbT, MgT, Lower ToT). Tephra volumes of the Malpaisillo and Monte Galán calderas accumulate to $152 \mathrm{~km}^{3}$ and classify most eruptions as $\mathrm{M}_{\mathrm{v}}=5.1$ or higher, of which the Tolapa Tephra with $126 \mathrm{~km}^{3}$ total tephra volume represents the largest eruption of the systems.

- If active again, its highly explosive nature can produce pyroclastic flows that constitute a major hazard at proximal to medial distances around the Malpaisillo/Monte Galán Calderas, whereas fallout deposits could affect the entire region around León, La Paz Centro, Nagarote, and Managua.

Supplementary data to this article can be found online at https://doi. org/10.1016/j.jvolgeores.2018.06.015.

\section{Acknowledgments}

We gratefully acknowledge the support by the Instituto Nicaragüense de Estudios Territoriales (INETER) in Managua, particularly by Dr. Angelica Muñoz and all the drivers who accompanied us during field work. SK acknowledges the German Research foundation (KU2685/2-2) for supporting this work and LS the Foundation "Volcanic Institute" Immannuel Friedländer for supporting the field work. We also want to thank A. Freundt, H. Wehrmann, J.C. Schindlbeck, Mario Thöner, and Fu-Lung Lin who either have been involved in early field work before the road construction or helped with the work in the lab. We also appreciate the helpful comments and suggestions of two anonymous reviewers.

\section{References}

Barckhausen, U., Ranero, C.R., von Huene, R., Cande, S., Roeser, H., 2001. Revised tectonic boundaries in the Cocos Plate off Costa Rica: implications for the segmentation of the convergent margin and for plate tectonic models. J. Geophys. Res. 106 (19), 207-220. Bice, D.C., 1985. Quaternary volcanic stratigraphy of Managua, Nicaragua: correlation and source assignment for multiple overlapping plinian deposits. Geol. Soc. Am. Bull. 96, 553-566.

Borgia, A., de Vries, B.V.W., 2003. The volcano- tectonic evolution of Concepción, Nicaragua. Bull. Volcanol. 65, 248-266.

Brown, S.K., Crosweller, H.S., Sparks, R.S.J., Cottrell, E., Deligne, N.I., Ortiz Guerrero, N., Hobbs, L., Kiyosugi, K., Loughlin, S.C., Siebert, L., Takarada, S., 2014. Characterization of the Quaternary eruption record: analysis of the Large Magnitude Explosive Volcanic Eruptions (LaMEVE) database. J. Appl. Volcanol. 3:5. https://doi.org/10.1186/ 2191-5040-3-5.

Carey, S., Sparks, R.S.J., 1986. Quantitative models of fallout and dispersal of tephra from volcanic eruption columns. Bull. Volcanol. 48, 109-125.

Carr, M.J., Patino, L.C., Feigenson, M.D., 2007a. Petrology and geochemistry of lavas. In: Buntschuh, J., Alvarado, G.E. (Eds.), Central America: Geology, Resources and Hazards 1. Balkema, Rotterdam, pp. 565-590.

Carr, M.J., Saginor, I., Alvarado, G.E., Bolge, L.L., Lindsay, F.N., Milidakis, K., Turrin, B.D. Feigenson, M.D., Swisher, C.C., 2007b. Element fluxes from the volcanic front of Nicaragua and Costa Rica. Geochem. Geophys. Geosyst. 8.

Dalrymple, G.B., Alexander, E.C., Lanphere, M.A., Kraker, G.P., 1981. Irradiation of samples for $40 \mathrm{Ar} / 39 \mathrm{Ar}$ dating using the Geological Survey TRIGAreactor. U. S. Geol. Surv. Prof. Pap. 1176,55

DeMets, C., 2001. A new estimate for present- day Cocos-Caribbean plate motion: implications for slip along the Central American volcanic arc. Geophys. Res. Lett. 28, 4043-4046.

Dengo, G. 1985. Mid America: Tectonic setting for the Pacific margin from southern México to northwestern Colombia. In: Naim, H.E.M., Stehli, F.G., Uyeda, S. (Eds.), The Ocean Basins and Margins. Plenum, New York, pp. 123-180.

Druitt, T.H., 1985. Vent evolution and lag breccia formation during the Cape Riva eruption of Santorini, Greece. J. Geol. 93 (4), 439-454.
Ehrenborg, J., 1996. A new stratigraphy for the Tertiary volcanic rocks of the Nicaraguan Highland. Geol. Soc. Am. Bull. 108, 830-842.

Fierstein, J., Nathenson, M., 1992. Another look at the calculation of fallout tephra volumes. Bull. Volcanol. 54, 156-167.

Fisher, R.V., Schmincke, H.U., 1984. Pyroclastic Rocks. Springer Verlag, Berlin Heidelberg New York (472 pp.).

Freundt, A., Bursik, M.I., 1998. Pyroclastic flow transport mechanisms. In: Freundt, A., Rosi, M. (Eds.), From Magma to Tephra: Modeling Physical Processes of Explosive Volcanic Eruptions. Vol. 4, pp. 173-245 Elsevier, Amsterdam/New York, Developments in Volcanology.

Freundt, A, Kutterolf, S. Wehrmann, H. Schmincke, H.U., Strauch, W, 2006a. Eruption of the dacite to andesite zoned Mateare tephra, and associated tsunamis in Lake Managua, Nicaragua. J. Volcanol. Geotherm. Res. 149:103-123. https://doi.org/ 10.1016/j.jvolgeores.2005.06.001.

Freundt, A., Kutterolf, S., Schmincke, H.U., Hansteen, T., Wehrmann, H., Pérez, W., Strauch, W., Navarro, M., 2006b. Volcanic hazards in Nicaragua: past, present, and future. Geol. Soc. Am. Spec. Pap. 412, 141-165.

Freundt, A., Hartmann, A., Kutterolf, S., Strauch, W., 2010. Volcaniclastic stratigraphy of the Tiscapa maar crater walls and sedimentary evolution of the Managua plain, Nicaragua. Int. J. Earth Sci. 99/6:1453-1470. https://doi.org/10.1007/s00531-009-0438-0.

Freundt, A., Grevemeyer, I., Rabbel, W., Hansteen, T.H., Hensen, C., Wehrmann, H., Kutterolf, S., Hamala, R., Frische, M., 2014. Volatile (H2O, CO2, Cl, S) budget of the Central American subduction zone. Int. J. Earth Sci. 103, 2101-2127.

Funk, J., Mann, P., McIntosh, K., Stephens, J., 2009. Cenozoic tectonics of the Nicaraguan depression, Nicaragua, and Median Trough, El Salvador, based on seismic-reflection profiling and remote-sensing data. Geol. Soc. Am. Bull. 121, 1491-1521.

Geilert, S., Freundt, A., Wörner, G., Kutterolf, S., 2012. Geochemical differences between along-arc and across-arc volcanics in west-central Nicaragua. J. S. Am. Earth Sci. 35, 38-50.

Hazlett, R.W., 1987. Geology of the San Cristobal volcanic complex, Nicaragua. J. Volcanol. Geotherm. Res. 33, 223-230.

Hradecky, P., 2001. Reporte Final para el Proyecto "Estudio Geológico y Reconocimiento de la Amenaza Geológica en el Área de Léon, La Paz Centro y Malpaisillo, Nicaragua". Servicio Geológico Checo (CGU) and Instituto Nicaragüense de Estudios Territoriales (INETER), Managua

Hunt, J.B., Hill, P.G., 2001. Tephrological implications of beam size-sample-size effects in electron microprobe analysis of glass shards. J. Quat. Sci. 16, 105-117.

Kutterolf, S., Freundt, A., Perez, W., Wehrmann, H., Schmincke, H.U., 2007. Late Pleistocene to Holocene temporal succession and magnitudes of highly-explosive volcanic eruptions in west-central Nicaragua. J. Volcanol. Geotherm. Res. 163, 55-82.

Kutterolf, S., Freundt, A., Perez, W., Mörz, T., Schacht, U., Wehrmann, H., Schmincke, H.U., 2008a. Pacific offshore record of plinian arc volcanism in Central America: 1. Along arc correlations. Geochem. Geophys. Geosyst. 9.

Kutterolf, S., Freundt, A., Perez, W., 2008b. Pacific offshore record of plinian arc volcanism in Central America: 2. Tephra volumes and erupted masses. Geochem. Geophys. Geosyst. 9.

Kutterolf, S., Freundt, A., Burkert, C., 2011. Eruptive history and magmatic evolution of the 1.9 kyr Plinian dacitic Chiltepe Tephra from Apoyeque volcano in west-central Nicaragua. Bull. Volcanol. 73, 811-831.

Kutterolf, S., Schindlbeck, J.C., Anselmetti, F.S., Ariztegui, D., Brenner, M., Curtis, J.H., Schmidt, D., Hodell, D.A., Müller, A.D., Peréz, L., Peréz, W., Schwalb, A., Frische, M., Wang, K.-L., 2016. A 400-ka tephrochronological framework for Central America from Lake Petén Itzá (Guatemala) sediments. Quat. Sci. Rev. 150:200-220. https:// doi.org/10.1016/j.quascirev.2016.08.023.

Kutterolf, S., Schindlbeck, J.C., Robertson, A.H.F., Avery, A., Baxter, A.T., Petronotis, K., Wang, K.-L., 2018. Tephrostratigraphy and provenance from IODP Expedition 352, Izu-Bonin arc: tracing tephra sources and volumes from the Oligocene to the Recent. Geochem. Geophys. Geosyst. https://doi.org/10.1002/2017GC007100.

Legros, F., 2000. Minimum volume of a tephra fallout deposit estimated from a single isopach. J. Volcanol. Geotherm. Res. 96 (1), 25-32.

Longpré, M.A., Stix, J., Burkert, C., Hansteen, T.H., Kutterolf, S., 2014a. Sulfur budget and global climate impact of the AD 1835 eruption of Cosigüina volcano, Nicaragua. Geophys. Res. Lett. 41:6667-6675. https://doi.org/10.1002/2014GL061205.

Longpré, M.-A., Stix, J., Costa, F., Espinoza, E., Muñoz, A., 2014b. Magmatic processes and associated timescales leading to the January 1835 eruption of Cosigüina volcano, Nicaragua. J. Petrol. 55:1171-1201. https://doi.org/10.1093/petrology/egu022.

Le Maitre, R.W., 1989. A Classification of Igneous Rocks and Glossary of Terms. Blackwell Scientific Publication, Oxford - London - Edinburgh - Boston - Melbourne, pp. 1-193.

Mann, P., Rogers, R.D., Gahagan, L., 2007. Overview of plate tectonic history and its unresolved tectonic problems. In: Buntschuh, J., Alvarado, G.E. (Eds.), Central America: Geology, Resources and Hazards. Balkema, Rotterdam, pp. 205-241.

Mason, B.G., Pyle, D.M., Oppenheimer, C., 2004. The size and frequency of the largest explosive eruptions on Earth. Bull. Volcanol. 66, 735-748.

McBirney, A.R., Williams, H., 1965. Volcanic History of Nicaragua. University of California Publications in Geological Sciences 55, Berkley and Los Angeles, pp. 1-73.

Morgan, J.P., Ranero, C.R., Vannucchi, P., 2008. Intra-arc extension in Central America: links between plate motions, tectonics, volcanism, and geochemistry. Earth Planet. Sci. Lett. 272 (1), 365-371.

Peréz, W., Freundt, A., Kutterolf, S., Schmincke, H.-U., 2009. The Masaya Triple Layer: a 2100 year old basaltic multi-episodic Plinian eruption from the Masaya Caldera Complex (Nicaragua). J. Volcanol. Geotherm. Res. 179 (3-4):191-205. https://doi.org/ 10.1016/j.jvolgeores.2008.10.015.

Pettke, T., Oberli, F., Audetat, A., Guillong, M., Simon, A., Hanley, J., Klemm, L.M., 2012. Recent developments in element concentration and isotope ratio analysis of individual fluid inclusions by laser ablation single and multiple collector ICP-MS. Ore Geol. Rev. 44:10-38. https://doi.org/10.1016/j.oregeorev.2011.11.001. 
Plank, T., Balzer, V., Carr, M., 2002. Nicaraguan volcanoes record paleoceanographic changes accompanying closure of the Panama gateway. Geology 30, 1087-1090.

Pyle, D.M., 1989. The thickness, volume and grain size of tephra fall deposits. Bull. Volcanol. 51, 1-15.

Pyle, D.M., 2000. Sizes of volcanic eruptions. In: Sigurdsson, H., et al. (Eds.), Encyclopedia of Volcanoes. Academic Press, New York, pp. 263-270.

Reid, M.R., 2003. Timescales of magma transfer and storage in the crust. Treatise on Geochemistry. 3, pp. 167-193.

Saginor, I., Gazel, E., Carr, M.J., Swisher III, C.C., Turrin, B., 2011a. Progress and challenges using $40 \mathrm{Ar} / 39 \mathrm{Ar}$ geochronology in Costa Rica and Nicaragua. Rev. Geol. Am. Central $45,75-85$.

Saginor, I., Gazel, E., Carr, M.J., Swisher III, C.C., Turrin, B., 2011b. New Pliocene, Pleistocene $40 \mathrm{Ar} / 39 \mathrm{Ar}$ ages fill in temporal gaps in the Nicaraguan volcanic record. J. Volcanol. Geotherm. Res. 202 (1), 143-152.

Schindlbeck, J.C., Kutterolf, S., Freundt, A., Straub, S.M., Wang, K.-L., Jegen, M., Hemming S.R., Baxter, A.T., Sandoval, M.I., 2015. The Miocene Galápagos ash layer record of IODP Legs 334\&344: Ocean-island explosive volcanism during plume-ridge interaction. Geology 43:599-602. https://doi.org/10.1130/G36645.1.

Schindlbeck, J.C., Kutterolf, S., Freundt, A., Alvarado, G.E., Wang, K.-L., Straub, S.M., Hemming, S.R., Frische, M., Woodhead, J.D., 2016a. Late Cenozoic tephrostratigraphy offshore the southern Central American Volcanic Arc: 1. Tephra ages and provenance. Geochem. Geophys. Geosyst. 17 (11):4641-4668. https://doi.org/10.1002/ $2016 \mathrm{GC} 006503$.

Schindlbeck, J.C., Kutterolf, S., Freundt, A., Straub, S.M., Vannucchi, P., Alvarado, G.E., 2016b. Late Cenozoic tephrostratigraphy offshore the southern Central American Volcanic Arc: 2. Implications for magma production rates and subduction erosion. Geochem. Geophys. Geosyst. 17 (11):4585-4604. https://doi.org/10.1002/ 2016 GC006504.

Schindlbeck, J.C., Kutterolf, S., Straub, S., Andrews, G., Wang, K.-L., 2018a. The 1 Ma-Recent Tephra Record at IODP Sites U1436 and U1437: insights into explosive volcanism from the Japan and Izu arcs. Island Arc https://doi.org/10.1111/iar.12244.

Schindlbeck, J.C., Kutterolf, S., Freundt, A., Eisele, S., Wang, K.-L., Frische, M., 2018b. Onand offshore correlations of Miocene to Holocene marine tephra layers in DSDP/ ODP drill sites offshore northern Central America. Geochem. Geophys. Geosyst. (submitted).

Schmincke, H.U., 2004. Volcanism. Springer Verlag, Berlin and Heidelberg, pp. 1-324.
Schmincke, H.-U., Kutterolf, S., Perez, W., Rausch, J., Freundt, A., Strauch, W., 2009. Walking through volcanic mud: the 2,100-year-old Acahualinca footprints (Nicaragua). Bull. Volcanol. 71, 479-493.

Schmincke, H.U., Rausch, J., Kutterolf, S., Freundt, A., 2010. Walking through volcanic mud: the 2,100 year-old Acahualinca footprints (Nicaragua) II: the Acahualinca people, environmental conditions and motivation. Int. J. Earth Sci. 99:279-292. https:// doi.org/10.1007/s00531-009-0438-0.

Scott, W., Gardner, C., Devoli, G., Alvarez, A., 2006. The AD 1835 eruption of Volcán Cosigüina, Nicaragua: a guide for assessing local volcanic hazards. Geol. Soc. Am. Spec. Pap. 412, 167-187.

Shaw, A.M., Hilton, D.R., Fischer, T.P. Walker, J.A Alvarado, G.E., 2003. Contrasting He-C relationships in Nicaragua and Costa Rica: insights into C cycling through subduction zones. Earth Planet. Sci. Lett. 214, 499-513.

Syracuse, E.M., Abers, G.A., 2006. Global compilation of variations in slab depth beneath arc volcanoes and implications. Geochem. Geophys. Geosyst. 7.

Van Wyk de Vries, B., 1993. Tectonics and Magma Evolution of Nicaraguan Volcanic Systems. (Doctoral Thesis). Open University, Milton Keynes (328 pp.).

Walker, G.P., 1983. Ignimbrite types and ignimbrite problems. J. Volcanol. Geotherm. Res. $17,65-88$.

Wehrmann, H., Bonadonna, C., Freundt, A., Houghton, B.F., Kutterolf, S., 2006. Fontana Tephra: a basaltic plinian eruption in Nicaragua. In: Rose, W.I., Bluth, G.J.S., Carr M.J., Ewert, J., Patino, L.C., Vallance, J.W. (Eds.), Volcanic Hazards in Central America. Geological Society of America Special Papers, pp. 209-223.

Wehrmann, H., Hoernle, K., Garbe-Schönberg, D., Jacques, G., Mahlke, J., Schumann, K., 2014. Insights from trace element geochemistry as to the roles of subduction zone geometry and subduction input on the chemistry of arcmagmas. Int. J. Earth Sci. 103 (7):1929-1944. https://doi.org/10.1007/s00531-013-0917-1.

Wehrmann, H., Freundt, A., Kutterolf, S., 2016. The 12.4 ka Upper Apoyeque Tephra, Nicaragua: stratigraphy, dispersal, composition, magma reservoir conditions and trigger of the plinian eruption. Bull Volc. 78. https://doi.org/10.1007/s00445-016-1036-1.

Weyl, R., 1980. Geology of central America. In: Bender, F.e.a. (Ed.), Beiträge zur Regionalen Geologie der Erde, 2nd ed Gebrüder Borntraeger, Berlin-Stuttgart (371 pp).

Wilson, C.J.N., Houghton, B.F., 2000. Pyroclast transport and deposition. In: Sigurdsson, H. (Ed.), Encyclopedia of Volcanoes. Academic Press, San Francisco, pp. 545-554. 